Visit our website for other free publication downloads

http://www.StrategicStudiesInstitute.army.mil/

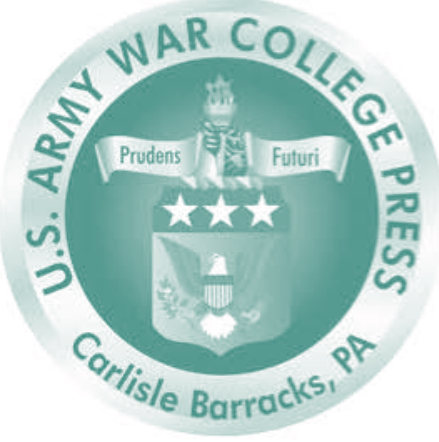

$\underline{\text { To rate this publication click here. }}$

\title{
SHARING POWER? PROSPECTS FOR A U.S. CONCERT-BALANCE STRATEGY
}

Patrick Porter 


\section{STRATEGIC STUDIES \\ INSTITUTE}

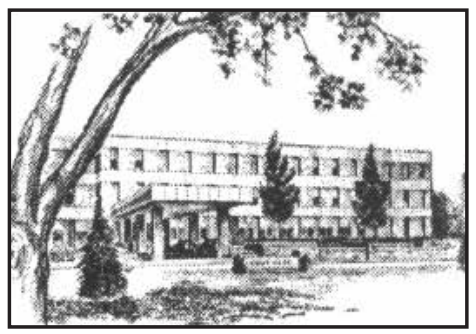

The Strategic Studies Institute (SSI) is part of the U.S. Army War College and is the strategic-level study agent for issues related to national security and military strategy with emphasis on geostrategic analysis.

The mission of SSI is to use independent analysis to conduct strategic studies that develop policy recommendations on:

- Strategy, planning, and policy for joint and combined employment of military forces;

- Regional strategic appraisals;

- The nature of land warfare;

- Matters affecting the Army's future;

- The concepts, philosophy, and theory of strategy; and,

- Other issues of importance to the leadership of the Army.

Studies produced by civilian and military analysts concern topics having strategic implications for the Army, the Department of Defense, and the larger national security community.

In addition to its studies, SSI publishes special reports on topics of special or immediate interest. These include edited proceedings of conferences and topically-oriented roundtables, expanded trip reports, and quick-reaction responses to senior Army leaders.

The Institute provides a valuable analytical capability within the Army to address strategic and other issues in support of Army participation in national security policy formulation. 


\section{Strategic Studies Institute \\ and \\ U.S. Army War College Press}

\section{SHARING POWER? \\ PROSPECTS FOR A U.S. CONCERT-BALANCE \\ STRATEGY}

Patrick Porter

April 2013

The views expressed in this report are those of the author and do not necessarily reflect the official policy or position of the Department of the Army, the Department of Defense, or the U.S. Government. Authors of Strategic Studies Institute (SSI) and U.S. Army War College (USAWC) Press publications enjoy full academic freedom, provided they do not disclose classified information, jeopardize operations security, or misrepresent official U.S. policy. Such academic freedom empowers them to offer new and sometimes controversial perspectives in the interest of furthering debate on key issues. This report is cleared for public release; distribution is unlimited.

$* * * * *$

This publication is subject to Title 17, United States Code, Sections 101 and 105. It is in the public domain and may not be copyrighted. 
Comments pertaining to this report are invited and should be forwarded to: Director, Strategic Studies Institute and U.S. Army War College Press, U.S. Army War College, 47 Ashburn Drive, Carlisle, PA 17013-5010.

This manuscript was funded by the U.S. Army War College External Research Associates Program. Information on this program is available on our website, www.StrategicStudies Institute.army.mil, at the Opportunities tab.

$* * * * *$

All Strategic Studies Institute (SSI) and U.S. Army War College (USAWC) Press publications may be downloaded free of charge from the SSI website. Hard copies of this report may also be obtained free of charge while supplies last by placing an order on the SSI website. SSI publications may be quoted or reprinted in part or in full with permission and appropriate credit given to the U.S. Army Strategic Studies Institute and USAWC Press, U.S. Army War College, Carlisle Barracks, PA. Contact SSI by visiting our website at the following address: www.StrategicStudiesInstitute.army.mil.

The Strategic Studies Institute and USAWC Press publishes a monthly e-mail newsletter to update the national security community on the research of our analysts, recent and forthcoming publications, and upcoming conferences sponsored by the Institute. Each newsletter also provides a strategic commentary by one of our research analysts. If you are interested in receiving this newsletter, please subscribe on the SSI website at www.StrategicStudiesInstitute.army.mil/newsletter/.

ISBN 1-58487-566-6 


\section{FOREWORD}

Grand strategy is an important subject. It is about the dialectical relationship between power and commitments, ends, and means. Grand strategy concerns not only the alignment of resources with goals, but how to conceive those goals in the first place. At root, it is about the identity of the security community. What kind of country does it want to be, and what kind of country does it have the power to be?

Debating U.S. grand strategy is a difficult subject in the public domain. First, it is often a reductionist debate. The author of this monograph contends that the overwhelming consensus among the two political parties is that Americans should focus on how to preserve America's liberal hegemony, in which the world is ordered under American leadership and dominance in order to secure its institutions and values at home. Dissent from that agenda, the author argues, is often dismissed too quickly as narrow isolationism. He observes that America does not have to choose between dominating the world and hiding from it. Instead, he asks how can Washington best remain a heavyweight among other heavyweights? He raises a Second important point: critics of America's liberal hegemony need to think harder about how alternatives should be designed and implemented, and what trade-offs, costs, risks, and dilemmas they would generate. He worries that too much collaboration and "pullback" could lead to a dangerous vacuum occasioned by regional rivalries and spirals of insecurity. Finally, he concludes that too much competition could lead to avoidable clashes between America and states bidding for regional dominance. Like Goldilocks's bears, it might be time to think about getting the mix "just right." 
This monograph is a small but important step in that direction. It does not offer a single blueprint, but constructively suggests a logic through which a new strategy could be hammered out, and some concrete ways in which new problems could be mitigated. The Strategic Studies Institute is pleased to offer this monograph as a contribution to the national security debate on this important subject.

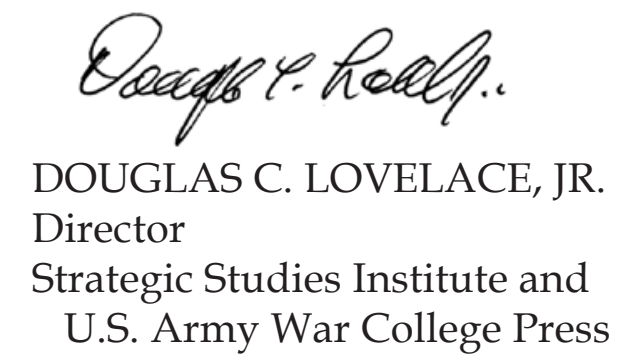




\section{ABOUT THE AUTHOR}

PATRICK PORTER is Reader in Strategic Studies at the University of Reading. His research interests are diplomatic and strategic history, U.S. and United Kingdom grand strategy, and the history of strategic thought. He is a fellow of the UK Chief of the Defence Staff's Strategic Forum, and a contributing editor to Infinity, a new online strategy journal. Dr. Porter is the author of Military Orientalism: Eastern War through Western Eyes (Columbia University Press and Hurst, 2009) and The Global Village Myth: Distance, Strategy and Modern War (Georgetown University Press, forthcoming). He authored articles in International Affairs, War in History, Diplomacy and Statecraft, the Journal of Strategic Studies, War and Society, Historical Research, Security Dialogue, Parameters, and the RUSI Journal, and has written op-eds for Le Monde Diplomatique, The Guardian, The Age, and The Sydney Morning Herald. Dr. Porter graduated from the University of Melbourne and holds a doctorate from the University of Oxford. 



\section{SUMMARY}

The Pax Americana and the grand strategy of hegemony (or "Primacy") that underpins it may be becoming unsustainable. Particularly in the wake of exhausting wars, the Global Financial Crisis, and the shift of wealth from West to East, it may no longer be possible or prudent for the United States to act as the unipolar sheriff or guardian of a world order. But how viable are the alternatives, and what difficulties will these alternatives entail in their design and execution? This analysis offers a sympathetic but critical analysis of alternative U.S. National Security Strategies of "retrenchment" that critics of American diplomacy offer. In these strategies, the United States would anticipate the coming of a more multipolar world and organize its behavior around the dual principles of "concert" and "balance," seeking a collaborative relationship with other great powers, while being prepared to counterbalance any hostile aggressor that threatens world order. The proponents of such strategies argue that by scaling back its global military presence and its commitments, the United States can trade prestige for security, shift burdens, and attain a more free hand. To support this theory, they often look to the 19th-century concert of Europe as a model of a successful security regime and to general theories about the natural balancing behavior of states. This monograph examines this precedent and measures its usefulness for contemporary statecraft to identify how great power concerts are sustained and how they break down. The project also applies competing theories to how states might behave if world politics are in transition: Will they balance, bandwagon, or hedge? This demonstrates the multiple possible futures that could shape and be shaped by a new strategy. 
A new strategy based on an acceptance of multipolarity and the limits of power is prudent. There is scope for such a shift. The convergence of several trendsincluding transnational problems needing collaborative efforts, the military advantages of defenders, the reluctance of states to engage in unbridled competition, and hegemony fatigue among the American people-means that an opportunity exists internationally and at home for a shift to a new strategy. But a Concert-Balance strategy will still need to deal with several potential dilemmas. These include the difficulty of reconciling competitive balancing with cooperative concerts, the limits of balancing without a forward-reaching onshore military capability, possible unanticipated consequences such as a rise in regional power competition or the emergence of blocs (such as a Chinese East Asia or an Iranian Gulf), and the challenge of sustaining domestic political support for a strategy that voluntarily abdicates world leadership. These difficulties can be mitigated, but they must be met with pragmatic and gradual implementation as well as elegant theorizing and the need to avoid swapping one ironclad, doctrinaire grand strategy for another. 


\section{SHARING POWER? \\ PROSPECTS FOR A U.S. CONCERT-BALANCE \\ STRATEGY}

\section{INTRODUCTION}

America's time as the undisputed hegemon of the world might be coming to an end. For better or worse, the United States has been the unipolar superpower presiding over a world system it, in large part, designed. Thanks to a range of interlocking problems, a growing number of observers now argue that the security environment of the early-21st century is becoming inhospitable to the kind of dominance that Americans were used to. Nothing is certain, and previous similar prophecies have turned out to be premature. Nevertheless, the decline of America's relative power and the end of unipolarity is now a sufficiently possible scenario as to warrant a serious debate about alternative grand strategies and an alternative role in the world.

In turn, this has serious policy implications for America's Landpower, its amphibious forces and their forward deployment abroad. America's land forces have been used to deter and respond to hostile states, and as a constabulary of sorts in pacifying countries against subversive guerrillas. These responsibilities have played a role in shaping the identity of America's land forces. To debate U.S. grand strategy is to debate what the country should do with its Army and Marines, how large and expensive they should be, and indeed what they are even for.

But if not American hegemony ... what? Short of either "coming home" or holding on to hegemony, is there a viable grand strategy to be found somewhere 
in the middle? Can the United States prudently carve out a role between an overreaching primacy and the insularity of a "waters edge" policy? Just as important, how should the policy be pursued? If the circumstances today make it prudent to begin retrenchment of America's commitments, on what theoretical basis should it be pursued? This monograph addresses these questions.

If we are seeing the coming of a more multipolar world, America's most realistic aspiration is to steer its way to becoming a primus inter pares among other rising states. This analysis weighs the prospects of an alternative strategy based on the logic of sharing power. It is written from the perspective of an Australian who is both reassured by and uneasy with the Barack Obama administration's reaffirmation of its alliance with Canberra, signaled most visibly by the arrival of U.S. Marines in Darwin. For Australia's sake as well as America's, it would be wise for the great powers to avoid two grave scenarios. The first would be an escalating Sino-American rivalry and even a clash that would place Australia in the crossfire between the country's main security provider and its main economic partner. The second would also be dangerous a complete U.S. withdrawal followed by an escalating rivalry between states such as China, Japan, and India, which would make for a poorer and more dangerous neighborhood.

If tomorrow's world will bring a redistribution of power internationally, then the only prudent path is to examine how the great powers could learn to live together and keep the peace, while retaining the capacity to thwart any would-be aggressor. That would mean the United States making a way to some extent to accommodate and allow for the rise of other 
states with a different grand strategy. That strategy would involve some combination of offshore balancing and great power concert, a mixture of cooperation and hedging that accepts renewed multipolarity as a fact of international life and looks to shape rather than control world politics. As argued here, both strategic history and a survey of future possible scenarios suggest that this may be difficult. But a difficult course in which America hopes for the best and prepares for the worst is better at least than an impossible one (holding on to the Pax Americana) or an irresponsible one (withdrawal and isolation).

The argument proceeds in three parts. Part I lays the competing grand strategies on the table, describing the critiques of current U.S. strategy and the arguments and theoretical underpinnings of proposed alternatives. It argues that multiple crises have exposed the serious imbalance between the resources and goals of current strategy. This section suggests that for all its adjustments, the Obama administration is working within the overarching grand strategy it inherited.

Part II introduces an under-recognized problem, namely, that even if U.S. primacy is no longer sustainable or prudent, other strategies may also entail serious dilemmas that have not been fully appreciated. These include the problem of unintended geopolitical consequences, the dangers of both balancing and bandwagoning behavior, the military presence problem, and the domestic politics problem. This section examines the historical precedents for collaborative security regimes, such as the 19th-century concert of Europe, arguing that while such strategies can succeed, they also are finite and must cope with the inherent difficulties of balancing competition and cooperation 
and sustaining international and domestic consent. Four converging trends are proposed to make possible a sober reappraisal of America's position and a shift to a new Concert-Balance role: the undesirability of unbridled competition, the military advantages held by defenders, transnational problems requiring collaborative efforts from the great powers, and hegemony fatigue among the American people.

Part III suggests how a new strategy could deal practically with the problems of design and implementation. It shows the different models of ConcertBalance and what they would entail, many of which are highly territorial in their emphasis. Each of these models would directly affect America's land forces, whether reducing and pulling them back entirely, or redeploying them within vital regions. As argued, it would probably be most prudent to balance the benefits of a partial withdrawal for the sake of conceding strategic space to rising states, with the benefits of a regional presence (including land forces in reserve) for the sake of retaining the capacity to deter and check any power that is not interested in sharing. Land forces conceivably would be part of this strategy. The ability to capture and hold territory would remain a part of deterrence and defense, even if new weapons technology profoundly raises the costs of doing so. Importantly, the author also proposes that a more collaborative grand strategy could be built partly on the basis of nonterritorial measures. It is not just a case of drawing geographic lines and arguing where to place forces, but a matter of managing interstate relationships in their entirety-for example, through arms control, measures to reduce the chances of accident and misperception, a refocusing on areas on which the states agree (such as energy security), and stepped-up 
diplomacy. I argue that for the strategy to have longevity and consent, elegant theorizing is less important than compromise, gradual pacing, and the patient building of domestic support. While this monograph will not prescribe any single blueprint, it identifies the trade-offs that a pragmatic shift in strategy will have to negotiate.

\section{PART I: THE STATE OF STRATEGY}

This monograph presents an argument about U.S. grand strategy. The subject of grand strategy - what it is and to what ideas and historical models America can turn-is getting renewed attention from the academic and policy communities. ${ }^{1}$ Grand strategy is the orchestration of ends, ways, and means in a context of actual or possible armed conflict, in the long haul and between peace and war. It is a theory of how to pursue national security and ensure a way of life by aligning power with interests. ${ }^{2}$ Grand strategy is the management of a chain of relationships among means and ends on many levels, an elusive effort to link these disparate things together. Strategy is thus distinct from both policy (the desired outcome) and operations (the exercise or use of the tools or the relationship between ways and means, such as the conduct of military campaigns). It is best conceived not as an identifiable actor or "thing," but as the bridge that fuses or relates them all together. ${ }^{3}$ Grand strategy represents the highest political realm in which these relationships are conceived. It aims at shaping an external environment in which the community's political institutions and values, its territorial integrity, and its way of life can be secure. It is for the long haul, eyeing the experience of security communities 
across generations. Within this big picture, conflict is seen not simply as a matter of victory and defeat, but judged according to proportional cost and long-term consequences. To strategize is to relativize. Through the lens of grand strategy, what seems like a bad military failure or withdrawal can be a prudent cutting of losses. An expensive diversion of resources by one generation can be a valuable investment for the next.

After its emergence as a superpower in the middle of the 20th century, the United States pursued a grand strategy of Primacy, or Hegemony. It is still debated precisely when this grand strategy was conceived and settled. Some strategists point to the thinking and calculations made during World War II, predating America's Cold War with the Soviet Union (194789). Its main principles were laid down in a Brookings Institution study of 1945, endorsed by the Joint Chiefs of Staff. ${ }^{4}$ This study argued for the prevention of any hostile powers or coalitions dominating the Eurasian landmass. Others argue that America's grand strategy under its new President, Harry Truman, was initially fluid, but between 1945-53 it solidified into an overarching project, with the Korean War acting as a catalyst. ${ }^{5}$ Others yet argue that even after the Cold War intensified, the Dwight Eisenhower administration still held out hopes for the recrudescence of Europe as a third force and nuclearized counterweight to the Soviet Union-a Europe onto which the United States could shift some of the burden - and that it was only with the John Kennedy administration that America finally settled on uncontested primacy as its preferred status in the world. ${ }^{6}$

Whenever historically it was established, the predominant strategy was as follows: Often described as the Pax Americana, or euphemistically as "leadership," 
this strategy was the pursuit of unchallengeable primacy by a nation that sees itself as the guardian of world order. It aims well beyond overcoming adversaries. It seeks to secure the United States and its way of life by spreading a democratic and market ideology that remakes the world in America's image. By becoming the anchor of world security, the United States attempted to forestall the re-emergence of a multipolar world of competitive power politics. By preventing any one power from dominating vital regions in Western Europe or East Asia, the United States could protect its interests throughout the world. Consequently, the United States looked to break the cycle of destructive power politics of the Old World, by harnessing its raw material power and exercising it through a new world order based on an architecture of international institutions designed by Americans. America looked to deter or overmatch enemies, reassure friends and potential rivals, and remain the sole benevolent superpower, with its domestic liberalism secure in a liberal globe.

This strategy has, as its interlocking parts: dissuasion, (to prevent potential rivals from challenging it); reassurance (to act as guarantor, underwriting the security of allies and partners to persuade them not to pursue military self-reliance that could create rival power centers); coercive nonproliferation (to prevent the spread of nuclear and weapons of mass destruction [WMD] capability); and especially with the "[George W.] Bush Doctrine," anticipatory war and muscular democracy promotion. This strategy implements this through a global military presence organized through a chain of bases; a network of permanent alliances and client states; and a pervasive spying and surveillance system - all underwritten by the Bretton-Woods 
financial order and the dollar as the world's reserve currency. More than interventionist in the world beyond its water's edge, it amounts to an "enduring intrusion." 7 This grand strategy was not unbroken and continuous. In the interlude under President Richard Nixon (1968-74), America attempted to transition to a more balance-of-power system, with burdens shifted to allies and regional clients (like the Shah's Iran). But Primacy eventually reasserted itself. ${ }^{8}$

The Pax Americana was both a grand strategy and an American self-image. It lived on beyond the Cold War and the demise of America's principal adversary, the Soviet Union. After that struggle, the United States reaffirmed its grand strategy of Primacy. This was laid down in the Pentagon's leaked Defense Planning Guidance draft in 1992,9 and reaffirmed in successive official National Security Strategies.

Makers of American strategy may disagree on the methods and temperament of statecraft, but mostly agree on the ends. Across both major political parties, it is a consensus that America should strive to remain the unchallengeable hegemon securing itself by extending market-democracy globally, with the debate focusing on how this is best done. Should America be consensually multilateralist or more unabashedly unilateralist, to what extent should it legitimize its power through international institutions or retain a free hand, and how much and where should it use its military power? These are not trivial questions, but they are mostly questions of technique, which are contested within a fundamentally shared grand strategic outlook. Successive administrations may believe that they are making a fundamental departure from their predecessors, but objectively may still be following the same broad assumptions. The Bill Clinton admin- 
istration of 1993-2001, for example, purported to shift America from "Containment" to "Enlargement" while President Clinton privately doubted whether grand strategy was even useful or desirable-but it objectively continued the project of former presidencies in a new, post-Cold War context, namely preserving and extending American hegemony by expanding the North Atlantic Treaty Organization (NATO), waging two wars in the Balkans, and at one point militarily confronting China over Taiwan. ${ }^{10}$

What now? The age of American-centric unipolarity may be giving way to a more multipolar world order. Here I do not seek to assert or refute the notion of American decline. There is already a vast literature on that contested subject. ${ }^{11}$ Instead, this analysis proceeds on the assumption that a nontrivial, major shift in power and wealth may be underway from West to East. ${ }^{12}$ In particular, we may be seeing through the rise of both India and China the realization of a geopolitical prophecy stretching back to Halford Mackinder and rearticulated now by Robert Kaplan. That prophecy is the coming of the Greater Indian Ocean era-or more accurately, the Greater Indian-Pacific era-becoming the pivotal arena of global politics because of its abundance of natural resources, its linkage of increasingly wealthy and growing states, and its critical position astride sea lanes. ${ }^{13}$

The change that may be underway does not necessarily mean that America is destined to fall but that the distribution of power and wealth in the world may bring an end to the era of the Pax Americana. That is, the shift of economic and then strategic weight to Asia may constrain America's capacity to dominate the international system and shape global events as it did 
since the fall of its major adversary in 1989-91. This shift is not absolute; it could be reversible and nonlinear. The United States, for its sheer size and resources, its sophistication in science and technology, its cultural appeal, and its battle-hardened military power, is likely to remain a strategic heavyweight for generations to come at least. Pound for pound for combat power, for example, in the area of naval aviation, the United States is without peer and will be for decades at least. Nothing is guaranteed, prophecies of decline have been wrong before, and we should not rule out a renaissance in America's global position. ${ }^{14}$ Potential challengers could also implode, and in the fields of natural resources, internal politics, and economics, China has its own profound internal fractures, vulnerabilities, and tensions. America's rivals cannot afford the United States to wane too much, given the reliance of export-oriented economies on the appetite of America's import market as the consumer-in-chief, and given China's own reserves of U.S. Treasury Bonds. That said, all world orders come to an end eventually. It would be foolish to dismiss the prospect of a power shift now because predictions were wrong in the past. Such a power shift is sufficiently possible to cause a deeper debate about what kind of alternative strategies would be most prudent. Soberly to imagine and prepare for a future in which America may no longer be the only superpower is simply to be realistic.

The status quo of the Pax Americana is unsustainable, at least in its current form. A mounting debt (at present it has reached $\$ 16$ trillion), record deficits, and competing demands on dwindling resources present a brute reality: that the United States probably cannot go on as the sole guardian of world order in the way in which it has been accustomed. ${ }^{15}$ Indeed, the pres- 
sure on public finances in itself constitutes a threat to the security of Americans' way of life. The Chairman of the Joint Chiefs of Staff identified record debt as the greatest threat to national security; the Director of National Intelligence warns that the economic crisis is America's gravest security peril; and former Secretary of Defense Robert Gates warned that the United States could become what President Eisenhower feared, "militarily strong, but economically stagnant and strategically insolvent."16 Dauntingly, Washington is faced with the need to restore its financial solvency, protect the dollar's reserve status, and meet its growing debt and interest payments, while also meeting growing obligations to a retiring population. This means it must make difficult "guns or butter" choices about cutting spending, especially discretionary spending, on defense. ${ }^{17}$ This would force the United States to choose between hollowing out its existing military or scaling back its commitments and missions for a reduced force to accomplish. These problems have grown over decades, but could metastasize quickly. ${ }^{18}$ America faces a "Lippmann Gap," in which its commitments exceed its power. ${ }^{19}$ The self-defeating behavior of fiscal indiscipline, accelerated by the wars in Iraq and Afghanistan, has saddled the nation with a range of domestic and international commitments that it struggles to uphold. ${ }^{20}$

Under these circumstances, holding onto the existing strategy - Primacy - would be unwise. It "forces a state to defend a vast and brittle Perimeter." ${ }^{21}$ In addition to making America's commitments exceed its resources, Primacy carries the "free rider" problem, of some allies and partners over-relying on Washington to shoulder the burden of their defense (such as some European NATO allies have long done). It car- 
ries the "moral hazard" problem of unintentionally underwriting the risky behavior of others by guaranteeing their protection. It potentially places the United States on a fatal collision course with other emerging powers, plunging both sides into a security dilemma whereby the measures they take to enhance their own security undermine other actors' positions and make them feel insecure, both then entering a spiral of distrust, competition, and arms buildup. Primacy can present the temptation of preventive war. An attempt to forestall the power shift through direct competition with emerging powers, even through preventive war, would be dangerous. Not only would it place the United States in conflict with states on whom it depends economically, but historically, preventive wars are launched to keep other states down, whether by Wilhelmine Germany or Imperial Japan, and tend to accelerate the very power shift they aspire to prevent. ${ }^{22}$ These wars can drive economies backward and turn regions into antagonistic camps. One significant cost of American primacy is entanglement in the politics of the Gulf, which played a nontrivial role in galvanizing the al-Qaeda terrorist network and its war with America as the "far enemy" for its role in sponsoring the hated "apostate regimes." ${ }^{23}$ In times of abundance, these problems possibly are manageable as an acceptable cost of a grand strategy. But America's strength is now strained to the point that it lacks the surplus reserve of power to respond to the contingent emergencies that its current course may produce.

The case for retrenchment of America's commitments, therefore, is compelling. Retrenchment is the retraction of grand strategic commitments in response to a decline in relative power, reducing the costs of foreign policy by redirecting resources away from 
peripheral to core commitments. ${ }^{24}$ It would involve some combination of the following: redefining interests and more strictly ranking core versus peripheral ones in order to reduce commitments; shifting burdens to allies and raising their contributions to their security interests; cutting military expenditures; avoiding militarized disputes and peripheral wars and reducing threats to interests through diplomacy; and devising cheaper and more effective forms of power and strategies for their use. A new grand strategy, however, would require more than making even major adjustments. It would be premised on a change in an underlying ethos from the accumulation of power and dominance of the international system to power-sharing, balance, and watchful accommodation within it.

Power shifts make new conflicts possible, but not inevitable. Conflict is not a law in periods of power transition, as some more pessimistic realists seem to think. Power transitions can be managed peacefully, as in the case of the Dutch Republic giving way to Britain in the 1700s. As we will see, historically from time to time, states have willingly formed concerts or regimes, agreeing to limit competition and co-exist warily. There is scope for discretion and choice as some states rise and others fall, passing each other on the way. ${ }^{25}$

If conflict during major power transitions is not a law, it is still a tendency. ${ }^{26}$ If history is a rough guide, as rising states like China become more wealthy and powerful, we should expect them to become more assertive in pressing their interests. Status quo powers (such as the United States) may well feel threatened, and are tempted to flex their muscles to tame their world back into equilibrium. We may already see the 
evidence for the propensity to increasing confrontation, for example, in the harder line states that are taking on maritime territorial claims in the South and East China Seas; in Washington's embrace of India as a strategic partner; and in China's development of a blue-water naval capability, its development of an anti-access and area denial shield, and its modernization of its nuclear weapons system and development of submarine-launched ballistic missile capability. At the time of this writing, Beijing has publicly launched its first aircraft carrier amidst simmering territorial disputes with Japan, over the Senkaku (or Diaoyu) Islands in the East China Sea and with the Philippines and Vietnam over resource-rich parts of the South China Sea. ${ }^{27}$ In addition to the contest for relative material power, prestige is part of the issue. China appears to be a dissatisfied state in the sense that its power is not yet sufficiently expressed internationally; its historic humiliations by foreigners have not yet been expiated; and its true status is not yet reflected through its historic frontiers in Taiwan, India-Tibet, or the South China Sea..$^{28}$

In a different context, with its main neighboring adversary, Saddam Hussein, taken off the board, an increasingly influential Iran regards itself as a natural great power in the Gulf. It is not as obvious a candidate as China to be a revisionist challenger, as it does not have the engine of a powerful economic expansion to underpin its bid for power and lend legitimacy to its regime. Nevertheless, the Gulf, like East Asia, is a region open to the effects of power transition. We are already seeing signs of renewed balancing against Iran, with the Arab Spring adding a potent revolutionary dimension to competition as Saudi Arabia and Iran compete in a Cold War contest in which popular protest and sectarian conflict endanger their 
client regimes and in which both throw their militaryfinancial weight into contested areas like Bahrain and Syria.

In this possibly deteriorating environment, how could alternative grand strategies be designed and implemented? The most prudent course would be to identify a middle-ground strategy somewhere between the poles of Primacy and Isolation. In terms of its first-order interests, the United States is essentially a materially secure state due to its distance, the power it can project to repel aggressors, its large nuclear stockpile, and the costs in the present era of waging offensive war and attempting conquest. The security of the United States need not depend on remaking the world in its image. But the United States still has nontrivial second-order interests in the security of the world's energy supply, the sea lanes and chokepoints such as the Straits of Malacca or the Straits of Hormuz, and in shaping the balance of power in critical regions, such as the Persian Gulf and in East Asia. As the U.S. maritime services argue, interests in the security of the global commons mean that it needs to have credible combat power in critical areas of the Indian and Pacific Oceans. ${ }^{29}$ The United States still exerts influence and helps set the agenda partly by virtue of its presence beyond its own shores. These interests and influences may not be strictly existential. But they are still serious.

So on what logic should a middle-ground strategy be based? U.S. grand strategy has attracted many overlapping efforts at categorization. It is difficult in all this taxonomy to identify and distinguish what really differentiates one from another. ${ }^{30}$ The debate on grand strategy is also mixed up in debate over making strategy in discrete conflicts, such as the Cold War or the Global War on Terror. ${ }^{31}$ 
For our purposes here, I identify three broad logics that could inform future strategy, those of Primacy, Isolation, and Concert-Balance. ${ }^{32}$ If we could plot alternative grand strategies on a spectrum, a ConcertBalance type would lie somewhere in the middle, between the poles of continued global domination and abandoning power politics and "coming home." It would relinquish hegemony as gracefully as possible, but remain engaged as a heavyweight willing to assert itself.

What exactly is a Concert-BalanceStrategy, and how does it differ from other strategies? A Concert-Balance strategy would concede strategic space and spheres of influence to other states, reduce America's peripheral commitments, contract the defensive perimeter and the military footprint, and perhaps exchange formal permanent alliances for informal temporary oneswhile asking other states to show reciprocal restraint and to contribute more to maintaining regional stability and security. The proponents of this strategy have formulated it in different ways. Michael Lind, Hugh White, and Stephen Van Evera lean more toward the concert side of the equation, proposing that the United States arrange a negotiated coexistence with emerging powers, while remaining present to some extent in vital neighborhoods such as East Asia or the Gulf. ${ }^{33}$ In what could be the next pivotal geopolitical region of the world, some propose (with varying confidence) a concert of Asia. ${ }^{34}$

Alternatively, offshore balancing theorists (such as Christopher Layne, Barry Posen, Christopher Preble, and Stephen Walt ${ }^{35}$ place more stress on the informal process of burden shifting and pulling back from America's forward commitments, and look to regional powers to check and balance against each other, with the United States as the "balancing" security guaran- 
tor of last resort. Only if one state were to achieve a preponderance of power and dominate its neighbors would the balancer fully intervene. In the words of Layne, offshore balancing "would define U.S. interests narrowly in terms of defending the United States' territorial integrity and preventing the rise of a Eurasian hegemon" in an increasingly multipolar world ${ }^{36}$ These theorists are probably more pessimistic about the chances of successfully building a concert, seeing international life as overwhelmingly competitive. In their view, the United States can live with continual power struggles, so long as they do not produce dangerous concentrations of power.

The premise of these alternatives is that America's most prudent course is to accept and accommodate what the writers see as a fact of political life, the return of multipolarity. The underlying logic of Concert-Balance grand strategies is that of watchfully sharing power with other major states, as a more sustainable way of securing America's way of life. As Michael Lind argues for the marriage of both principles of concert and balance:

The Concert-Balance strategy represents the best national security strategy for the United States in an era of emerging multipolarity and domestic budget constraints. It abandons the exorbitantly expensive and ultimately doomed attempt to forever forestall the emergence of other great powers by means of dissuasion of potential foes and reassurance of friends, in order to realistically prepare for the U.S. role as a leader of concerts and alliances in a multipolar world. It draws both on American idealism - the dream of collective security shared by Woodrow Wilson and Franklin Roosevelt with millions of people around the world - and on American pragmatism - the successful experience of the United States during the World Wars and Cold War as a leading member of great-power 
alliances rather than a solitary superpower. Since the end of the Cold War, the United States has lacked a credible vision capable of guiding American national security policy in the multipolar world of tomorrow without bankrupting the economy or exhausting public support. The Concert-Balance strategy provides that missing vision. ${ }^{37}$

Pulling back and limiting U.S. liability would persuade other states to shoulder a greater burden of counter-hegemonic balancing. As America does less, others would have to do more. At the same time, the United States can disengage from formal Eurasian commitments and make significant budget cuts without compromising national security.

However, in addition to attempting to negotiate a coexistence with other major powers, America with this strategy would also seek to cover its bets in case other states turn out to be bad sharers. It would thus husband its military-strategic capabilities and accumulate surplus power to counterbalance against any would-be aggressor, and act as a security provider of last resort. Taking Ken Booth and Nicholas Wheeler's triptych of transcender, mitigator, and fatalist visions of world politics, a Concert-Balance strategy falls prey neither to the hopes of utopians who seek to transform the world, nor to those fatalists who see international life as an inherently conflictual, predatory, and zerosum game. It holds that insecurity can be ameliorated for a time and that conflict can be limited and localized, but that the mischief of the anarchic world can never be finally eliminated. ${ }^{38}$

This strategy does not rule out intervention or the use of force, but remains " at heart a watching and reactive strategy, not . . . a precautionary and preventive one." ${ }^{39}$ Its ultimate goal is not to prevent war outright, 
but to ensure that any conflict minimizes costs and maximizes gains for U.S. relative power. Strategists who take the above positions do have their differences. Where they implicitly or explicitly differ is how this new strategy should be operationalized, what bargains would need to be struck to make a concert work, and what moving "offshore" means in practice. The final chapter of this work will identify and weigh these differences.

What historical models would inform this kind of grand strategy? There are cases in international history that can give a rough guide to what collaborative regimes and power balancing look like, even while they are imperfect analogies. ${ }^{40}$ Crucially, each case has its drawbacks. The record suggests that effective retrenchment and the adoption of a new grand strategy is possible, but that in practice active balancing is hard to pull off without entanglement and unintended consequences. For their part, security regimes are impermanent, they rely on a level of power equality that does not always exist, and their very success contains the seeds of their failure.

From U.S. history, there are some ruthless examples of balancing behavior. By limiting and delaying its intervention in the European war of 1939-41, the United States was able to help keep Britain and the Soviet Union in the war while the two continental giants-Germany and the Soviet Union - were worn down, preventing both from becoming masters of Eurasia. As a result, America emerged as a nuclear superpower and the only state that directly materially benefited from the most destructive war in history. The change in power relativities as a result of World War II left America's might artificially high in $1945 .{ }^{41}$ The United States experienced unprecedented industrial expansion. It reached the highest per capita produc- 
tivity in the world, the highest standard of living, and domination of the world's gold reserves. The United States also became the largest creditor and exporter. Its capacity to project power globally with long-range bombers and carrier task forces was unparalleled, leaving formerly great powers such as Britain (whose empire it helped dismantle) and France in security dependency on Washington. We must note, however, that this is still a violence-based example. Such a strategy still led to full-scale mobilization and a vast military effort, a precedent that some find discouraging as a model for future grand strategy making. Similarly, one precedent for offshore balancing is the backing of Saddam Hussein's Iraq as a counterweight to revolutionary Iran, a bloody strategy that had mixed results - containing a potential regional hegemon and preserving a power balance in the Gulf, but entangling the United States in an ongoing forward deployed presence and a decade of containment. This strategy also taunted the United States with complicity in one of the most catastrophic wars in the region in modern times. This is again a precedent that will cause disquiet for some observers.

History also offers some less violent diplomatic precedents in which overstretched states have found effective diplomatic ways of reducing threats, shifting burdens, and realigning with former adversaries, all to close the gap between their power and their commitments. One is Edwardian Britain at the turn of the 20th century. In the wake of the Anglo-Boer war of 18991902, Britain found itself overextended and facing the rise of Imperial Germany as an economic powerhouse building a large navy and a revisionist state that posed a challenge to the Pax Britannica. Furthermore, Germany's rising power coincided with that of other maritime nations such as Japan and the United States. 
To adapt to this inhospitable environment, Britain conceded strategic space to the United States over its own hemisphere in the Americas and the Caribbean, allied itself with Japan as a counterweight to Germany and Russian expansion in Asia, and conciliated with France and Russia. ${ }^{42}$ This grand strategy on its own terms was a pattern of effective strategic adjustment. It fell short, however, of overhauling the deep economic issues linked to the problem, and it was mostly unstated and fragmented. Moreover, by accommodating or settling with its main imperial rivals, Britain helped the encirclement of its most feared continental rival, thereby stimulating further antagonism and the breakdown of European order.

American diplomatic history also offers a constructive case. Over three presidencies between 1968 and 1980, Washington opened the way to full diplomatic relations with China, reducing potential threats to its interests in Asia; it negotiated the Camp David Accords and realigned itself with Egypt; resolved the Panama question; achieved modest successes in persuading allies from NATO to Japan to increase their defense budgets; and achieved arms control agreements with the Soviet Union on ballistic missile defenses and strategic offensive weapons. As Samuel Huntington noted, "Consider how different the world would look and what the demands would be on U.S. resources if China were threatening aggression against American interests in Asia, if Egypt were a Soviet ally and military base, and if the Panama Canal were under intermittent attack by guerrilla-terrorists." ${ }^{43}$ As a result in large measure of the U.S.-China détente, America emerged from the Vietnam War with none of its allies straying or its adversaries falling out, and with its overall strategic position in Asia bolstered rather than weakened. 
The great historical model for a security regime or concert is that of 19th-century Europe, formed in 1815 at the Congress of Vienna after the defeat of Napoleonic France and its bid for continental hegemony. Europe's concert was a "security regime," or "geostrategic cartel," of a set of relationships and practices designed to build cooperation between the victorious states. ${ }^{44}$ It did not always achieve consensus, or eliminate disagreements or even occasional armed conflicts. But its members did cooperate to manage crises and prevent a generalized, major international conflict between them. It was an impermanent solution. Historians dispute the causal relationships that produced the stability and relative peace associated with the concert, and they dispute the timing and causes of its demise. They probably were united around the gains from cooperation and the costs for defection, were impelled by sheer exhaustion from the Napoleonic wars to avoid another major conflict, and may have been culturally bonded by shared aristocratic values and a sense of an international European community of common security interests.

The 20th century has also seen the recrudescence of the idea: The United Nations Security Council (UNSC) was formed to embed a concert of major powers, or in the earlier words of President Woodrow Wilson, a "community of power." Moreover, there are echoes of an informal concert in today's management of international order by the leading states-though the concert principle reflected in this architecture was overshadowed by the dyadic Cold War competition between two of its leading members, and ever since has been overshadowed by America's unprecedented level of unipolar dominance. ${ }^{45}$

In defining Concert-Balance strategies, it is important to clear up three areas of conceptual confusion. 
First, offshore balancing is not the same as isolationism. While isolationists might be drawn to some of the policy implications of offshore balancing, the two approaches are distinct: Both involve abstention from foreign military commitments to a greater or lesser degree, but balancing strategies in principle allow for more of an "over the horizon" presence in the region, remain concerned about the balance of power abroad, and are not strictly committed as isolationists are to neutrality.

Second, offshore balancing is a grand strategy, but is sometimes treated as a matter of tactical/operational military posture and style, an aversion to forward deployed land forces or ground military expeditions in favor of the standoff ability to punish/interdict through naval air strikes. Taken literally, in this context offshore balancing means removing garrisons in various regions, and parking the U.S. Navy over the horizon to intervene only occasionally. For Robert Pape, it entails the use of air and naval assets rather than direct occupation. ${ }^{46}$ For John Mearsheimer, it means minimizing America's military footprint in the region while ensuring that no single power dominates it, reducing incentives for anti-American terrorism. ${ }^{47}$ These proposals in themselves do follow the logic of extricating the United States from costly ground commitments, but could just as easily stand as discrete measures in maintaining a grand strategy of Primacy based on raiding and punitive strikes. Ultimately, an offshore balancing strategy must go beyond taking steps to minimize terrorist blowback and is really intended to refocus the United States on what political realists regard as the central question of its relations with other major states.

Third, contrary to the claims of some, the current grand strategy remains one of Primacy. ${ }^{48}$ The Obama 
administration has recalibrated U.S. statecraft in some significant ways, most notably in the pivot toward Asia as its priority, the downgrading of America's commitment to European security, a de-emphasis on counterinsurgency and nation-building, and reshaping the military to make it more "standoff" in its posture and its missions. Obama is already taking some steps at retrenchment as laid out in the Defense Strategic Guidance and shifts in its military posture. ${ }^{49}$ But in words and deeds, the Obama administration is still trying to hold on to American hegemony and in particular, primacy in Asia, by bolstering its own presence while restraining China's rise in the Pacific. The Defense Strategic Guidance leaves much scope for interventionism, even while it has abandoned expeditionary land adventures to pacify and rebuild third world countries. Secretary of State Hillary Clinton declared a "new American moment" and reaffirmed America's commitment to global "leadership," 50 though in a subsequent speech she emphasized U.S.Chinese partnership. ${ }^{51}$ President Obama's speech to the Australian Parliament in November 2011 rededicated the United States to being a Pacific power with an enhanced presence in the region-underwriting its security and seeking a cooperative relationship with Beijing but inviting it into an American-centric order. ${ }^{52}$ In its behavior, the United States augments its naval-air presence in Asia and reinforces strategic ties with allies in the shape of Marines deployed to northern Australia and military assistance to states potentially in China's shadow. The United States has also recently consolidated its strategic partnership with India, which is probably partly a hedge against China's rise. ${ }^{53}$ In practice, there is already in the current strategy an effort to spread costs by encouraging burden sharing, especially in East Asia. But 
Obama's statecraft is still highly interventionist, and its overall goal is unchallengeable primacy through permanent presence.

Under Obama, the United States attempts to pursue the existing inherited grand strategic goal (the preservation of American primacy) while adjusting the ever-shifting mix of military supremacy, deterrence, reassurance, and democracy promotion in an apparently increasingly important part of the world where economic weight and political ambition are moving. The overriding message is that of sustaining an American-centric order with little room for strategic parity. In other words, Washington invites China to cooperate harmoniously as a stakeholder, from an unequal position. This is some distance from a power-sharing agreement or security regime. Obama's adjustments do not yet represent a fundamental shift in America's grand strategic aims or its underlying rationale. Importantly, this is how China perceives U.S. strategy, that "Washington wants cooperation on its own terms, seeks to deter Beijing from developing a military capability to defend its interests, and intends to promote change in the character of the Chinese regime." ${ }^{54}$

\section{PART II: NO FREE LUNCHES: DILEMMAS, TRADE-OFFS, AND OPPORTUNITIES}

In grand strategy, as in life, there are no free lunches. An unbending commitment to Primacy may well be unaffordable and imprudent. But retrenchment and a new strategic role are likely to entail serious costs and risks. Here in Part II, I survey the main critical objections that have been made against Concert-Balance strategies. ${ }^{55}$ These critiques in part are overblown, as I 
argue. But other aspects of them stick. The more astute criticisms should inform and temper how a different strategy is conceived, designed, and executed. At the same time, the uncertain international environment is also throwing up opportunities and trends that could work in favor of a change in American statecraft.

The debate about moving the United States into a more modest, withdrawn role boils down to a question of chaos: How much would its retrenchment or withdrawal unleash, and how much chaos can the United States affordably live with? It is worth recalling that offshore balancers do not claim to offer a solution to international insecurity. After all, the strategy's main advocates are pessimistic realists. They regard competition and insecurity as hard-wired into the anarchic world in which we live. Rather, they seek to keep the United States away from the eye of geopolitical storms and transfer conflict to others, leaving crisis management in the first instance to local states. They resist the widespread assumption that international security must rest upon the adult supervision of a singular superpower, reminding us that for America to retrench and burden-shift is not the same as making other states defenseless. That is the difficulty with Aaron Friedberg's accusation that retrenchment would betray "America's long history of coming to the aid of fellow democracies, a decision that could be construed as abandoning some of them to their fates." ${ }^{56}$ Apart from its selectively rose-tinted view of American diplomatic traditions, this argument underestimates the capacity of other countries to take on a greater burden of balancing and counterbalancing themselves. That would be an obstacle to his dark scenario, in which an unchecked Chinese domination of East Asia could give it preferred access to, if not full 
command over, the region's vast industrial, financial, natural, and technological resources, and a base for further power projection. Besides, by reducing the chances of a security dilemma, an accommodation of China's growth (within limits) that prevented allout competition could enhance rather than threaten the security of the democracies that Friedberg cares about. At the same time, a Concert-Balance strategy would reckon that the chances of China slowly politically liberalizing would be greater if its leaders could not easily rally nationalism by claiming that their state was being encircled and threatened.

According to more optimistic appraisals, an American retreat from hegemony would lead to a manageable level of strife that would benefit U.S. security interests. The withdrawal of America's military supervision would see the re-emergence of natural checks against predatory behavior - namely a return to the logic of balancing and equilibrium, should any state threaten its neighbors. In addition, any competition would be limited and bounded by today's military technology. Nuclear weapons have made conquest by other states virtually impossible and prohibitively costly. They generally dampen security competition among major powers. As cooperation is imperative and competition increasingly costly, never before have there been such strong incentives for interstate peace, stability, and cooperation. In this new space, a new security regime of collaboration could be forged, hammered out, and negotiated with emerging powers such as India and China. There are new, transnational threats that require joint response and could form the basis for a concert. Just as the 19th-century concert was bound together by a common fear of mass revolution and the wars that attended it, so too could the major powers of the 21st century organize and collaborate 
around the unifying force of common threats such as catastrophic terrorism, WMD proliferation, and threats to the global commons such as climate change.

Against this optimistic reckoning, there are darker possibilities. A return to a stable multipolar balance of power is not necessarily guaranteed. Neither nuclear weapons nor new global threats might suffice to prevent the resumption of competition and security dilemmas. Even if nuclear weapons do have an overall restraining effect and preclude the kind of conquest and expansionism that traditional balance-of-power strategy fears, states might still engage in security competition of other kinds, such as proxy wars, arms and alliance races, and high-stakes confrontations. Without the world's sheriff as security guarantor, there could be an alarming cycle of distrust, military buildup, regional arms races, escalating competition, and war in key regional centers such as the Gulf or Asia-Pacific. Furthermore, it is not clear that balancing will be the dominant response to America's withdrawal. States deprived of American security guarantees might "bandwagon" rather than "balance," aligning themselves with regional hegemons rather than counterbalancing them, leading to a Chinese East Asia or an Iranian Gulf. These would form the kinds of regional blocs that have traditionally been unwelcome to U.S. strategists. Even if Concert-Balance theorists are right and balancing does prevail over bandwagoning, the United States would have to be prepared either to live with, or to mitigate, the effects that could flow from the withdrawal of America's reassuring and dissuading presence.

What should we make of the objection that sharing power to burden shift will in turn invite security dilemmas, as emerging powers re-arm, expand their 
ambitions, and enter a new era of confrontation? Critics may be astute to point out that confidence in the natural balancing dynamic can overlook the destabilizing effects of creating power vacuums that would not necessarily directly threaten the United States, but still be bad for its interests. As they point out, if the United States does less, states may be less confident that Washington "has their back." To switch metaphors, if the American cork is then removed from the Gulf and Asian bottles, those regions may be in for new and dangerous waves of saber rattling and instability. As two observers put it:

Forward-postured forces also reassure allies of the United States' commitment to their security. On the Korean Peninsula, for example, the presence of some 28,000 U.S. personnel reminds Seoul that the United States stands ready to defend South Korea against North Korean aggression. Further south, U.S. naval and air forces engaged in Australia, the Philippines, Singapore, and Thailand give allies in Southeast Asia greater confidence that the United States will not abandon the region at a time of great change and uncertainty. ${ }^{57}$

But even with the United States still in a forwardleaning role and Obama's pivot toward Asia, a rise in competition flowing from a sense of insecurity is already happening to some extent. The evidence for it lies in the pattern of rising defense investment, territorial disputes, and flare-ups. Asian states are already spending much more on their defense as they fear their security environment deteriorates. According to latest findings of the International Institute of Strategic Studies (IISS), Australia, South Korea, Japan, India, Malaysia, the Philippines, and Singapore all raised their defense spending significantly over the past few 
years. ${ }^{58}$ Apart from the effects of inflation, this can be explained as the result of several converging factors, including uncertainty over the implications of China's rise, doubts over the credibility of U.S. security guarantees, and economic growth in East Asia. In response, U.S. strategy already contains a mixture of security provision and burden sharing. Regional states are not waiting for a shift in U.S. grand strategy to feel insecure and are actively taking measures to help themselves. A dangerous multipolarity may be on the horizon, whether America welcomes it or not. The strategic choice for the United States is whether to resist this development-placing greater strain on its overstretched resources and putting it on a collision course with other powers - or adjust to and manage this change as gracefully as possible.

There are also practical, logistical, and domesticpolitical problems entailed in a Concert-Balance strategy. How is the United States to act as an offshore power, intervening selectively to protect the equilibrium of world order, without the architecture of a forward military presence, a basing network, or an onshore military capability? Would prudent balancing from a distance still entail a withdrawal to its own hemisphere, or would the United States need to retain a basing presence and ability to secure the global "commons" on which it depends by projecting power over potential flash points or maritime choke points such as the Spratley Islands, Taiwan Straits, Straits of Hormuz, or the Malacca Straits? Intervening militarily as a balancer may also be made more difficult by innovations such as nuclear weapons, intercontinental missiles, and information technologies, all of which enable regional defenders to place high costs on a would-be offensive interloper. If the strengthening of "access/area denial" makes direct intervention too 
expensive or too escalatory, other problematic forms of competition would have to be considered, such as bankrolling temporary allies or proxy wars.

The greatest practical problem with offshore strategies is the concrete need any balancer would have for military bases abroad. It is not the case that technological sophistication and long-range weapons systems remove America's need for an onshore military capability. Indeed, ever-more-sophisticated technology in some ways is more demanding of physical support than its antecedents. Jet fighters, tanks, and helicopters need constant maintenance, fuel, and logistical backup. Ship crews need food and harbors. To wage war against Iraq in 1991, a relatively weak opponent compared to the U.S.-led coalition, the United States still had to amass a gigantic quantity of supplies in Saudi Arabia. ${ }^{59}$ Effective military power, especially at long range, lies not only in doctrines of force employment or the volume of firepower, but in the capacity to sustain operations. Therefore, any effort to reduce America's security footprint should take into account the need to leave regional states confident enough in America's will to act as a balancer that they are willing to offer access to bases.

Balancing from abroad may be more violent, more intense, and more entangling than sometimes assumed. The major historical example of an offshore balancer, 18th-century Great Britain, worked hard to stay aloof from continental commitments, but balancing still led it into a range of European wars including that of the Spanish Succession (1701-14), the Austrian Succession (1740-48), the Seven Years' War (1756-63), and the War of the First Coalition (1793-97), as well as the war against France in the American Revolutionary War (1775-83). Then there were proxy struggles in 
colonial India and in the Vendee uprising, among others. For the present, Michael Lind argues that, in the absence of unlikely major interstate wars, balancing would entail not only the training of indigenous forces or emergency relief, but also "proxy wars" reminiscent of the Cold War. ${ }^{60}$ This would place in jeopardy one of the main imperatives of a new grand strategy, which should be to involve an overstretched superpower in fewer conflicts, especially costly peripheral ones that do not directly threaten it.

Another difficulty is the problem of bandwagoning. As Krepinevich argues, a reduced U.S. strategic presence may open the way not to balancing, but to China's strategy of "Finlandization," if Beijing's goal is:

not to establish its pre-eminence in the region by fighting a war. Rather, the Chinese want to do so by winning a 'bloodless' victory, by convincing Seoul, Taipei, and Tokyo that, given the altered military balance in East Asia, they should accommodate Chinese interests and reduce ties with the United States. ${ }^{61}$

The risk of a region-wide bandwagoning, historically speaking, is low, but not remote. ${ }^{62}$ As we will see, Taiwan in fact is consciously Finlandizing. But what of India, Japan, or South Korea? For bandwagoning to occur, a number of conditions normally are needed. States that behave in this way are normally relatively weak; they see the dominant state as an appeasable threat, and they lack available or potential allies. The first criterion may apply to Taiwan, given its proximity to a powerful neighbor, but the other two apply far less to India or Japan. South Korea may be a candidate for a partial drift toward Beijing in the event of a U.S. withdrawal, but outright bandwagoning would be 
made less likely by the role of its historic adversary, North Korea, also China's client. In the Gulf, there are few regional states powerful enough to predominate to the extent that others would be tempted to bandwagon. Iran's resurgent influence would still probably be countered by Saudi Arabia, Israel, and Egypt. In the event of a U.S. withdrawal from formal security commitments in Eastern Europe, it is not clear that states like Poland or the Czech Republic would regard Moscow as an appeasable threat. Equally, we could reasonably expect a reassertion of Russia's geopolitical influence nearer its frontiers, with states such as Georgia and the Ukraine less confident that the United States, through NATO, would have their back. Realistically, a power-sharing relationship with Russia would probably have to concede Moscow strategic space in its own backyard. Thus, overall, there may be bandwagoning to an extent for more vulnerable states that are physically closer to China and Russia, but not for a bandwagoning cascade to the extent that some fear.

This raises an important point about the role of allies and fellow democracies in American grand strategy. Effective strategy requires the recognition of limits, the limits of both power and commitments. To embrace an open-ended commitment to the cause of democratic liberty is to abandon limits. Even the defense of Western democracy has historically involved bargaining and collaborating with authoritarian allies, both with Stalinism in World War II and with a range of dictatorships in Europe, the Middle East, South America, Africa, and Asia during the Cold War. Consider, for example, the question of NATO expansion and the charge that America might abandon its democratic allies to Russia. Russia has an orbit that 
it will jealously protect, just as America does. Instead of flirting with the notion that NATO will draw in states in others' backyards, or even protect them in a crisis, it is more prudent to accept that this is just geopolitical bad luck for the likes of Southern Cyprus, Georgia, or the Ukraine, whose inclusion could draw NATO into conflict or give opportunities to secessionists or nationalists to manipulate NATO into a crisis. NATO is not obliged to do what it cannot prudently do, or what it cannot do without taking on suicidal risks; in this case, an eyeball-to-eyeball confrontation on a militarized frontier, or an Article $\mathrm{V}$ commitment to war with Russia. NATO does not exist to defend vulnerable states that live in the shadow of giants or to be a crusading Delian league of democracies. It exists to protect the North Atlantic world. Part of that task is to negotiate distance with outside powers and reassure them from a position of strength, rather than close the gap and antagonize them from a position of overreach. ${ }^{63}$

Just as criticisms have been leveled at offshore balancing strategies, so too has the notion of a security regime attracted doubters. Consider the concert of Europe as the major case in international history. This debate is complicated by the problem that historians disagree on what sustained and what undermined the concert, and even when we should date its life and death. ${ }^{64}$ But from the balance of the historiography, we can confidently assume that such regimes may be impermanent and hard to sustain. A successful regime requires a common perceived interest, most powerfully provided by a common perceived threat, and such threat perceptions are normally not permanent. Security regimes require an unusual level of restraint in their members, who expect gains to flow from their 
cooperation and who are motivated to avoid the costs that defection would bring. Collaboration needs trust and the restraint of competitive behavior, and this is hard to forge, given the uncertainties of detecting what others are doing - why they seek arms, the difficulties of predicting who allies and enemies will be, and the suspicion that other members of the concert will cheat. Ironically, by reducing fear and suspicion, promoting cooperation, and lessening the security dilemma, such regimes may contain the seeds of their own failure by encouraging states to push harder for individual gain, behave competitively, and thereby erode the regime itself. ${ }^{65}$

The 19th-century European concert is hardly an exact parallel to today. As some have observed, it was hammered out from a common original crisis (the Napoleonic wars), a common European elite diplomatic culture, a shared fear of revolution, and rough power parity between members of the concert. Today, we are arguably dealing with disparate cultures, not bound together by the same fear of revolution, with power parities possibly shifting rapidly. ${ }^{66}$ But in other ways, conditions could be ripe for a power-sharing agreement. As already shown, both defense-dominant military technology and delicate economic relationships in a mercantile age would make it prudent to negotiate an arrangement for reciprocal restraint. In addition, while there is no common political specter such as mass revolution, or a common national adversary such as a resurgent Napoleonic France, there are common areas of material interest-indeed, threats to the global commons - that could be the focal point and source of motivation. These include nonproliferation and the prevention of nonstate actors obtaining WMD and the securing of loose nuclear materials, energy 
security, natural disasters, diseases, and epidemics. In addition to these common areas, the major states in the world are faced with a global financial crisis in which they cannot afford the major consumer market of America to fail too quickly or too deeply.

The most discouraging difference between the 19th-century example and today's conditions lies in the different configurations of power. The concert of Britain, Russia, Prussia, Austria, and then France contained states that were much more closely comparable in terms of military-strategic might than, say, the United States and its potential concert partners today. Moreover, they were exhausted by an epochal war and disenthralled from further conflict. The Congress of Vienna in 1815 represented the collective effort to address a common problem and forge a broader sense of an international interest. Opinion in Washington may well resist the suggestion that the United States should allow for a rebalancing of power in the medium-term future. For proponents of a modern-day concert of India, Russia, China, America, and some combination of European states, the strongest counterargument would be that the shift of wealth from West to East (if it continues) will bring these states closer to rough parity.

To bolster such an arrangement with deeper levels of trust, it would be desirable to intensify diplomatic communication and dialogue. A concert today, like its 19th century antecedent, pivots on horse trading, compromise, and ongoing negotiation. It therefore should work as an informal arrangement rather than rely on a formal institutional architecture.$^{67}$ A shared sense of a European, Gulf, and Asia-Pacific security community would be useful. Even if this were unrealistic, concerts on a day-to-day basis require a lot of diplomatic spadework. To maintain a collaborative order based 
on mutual restraint and trust would need a great deal of summitry as well as lower-level communication. As the final section will argue, stepped-up diplomacy would need greater investment and resources.

The most difficult, possibly the most fatal, obstacle to forging a security regime is that it is easily caricatured. It would be crudely accused of representing "appeasement." In American (and Australian) diplomatic history, this is a strong and enduring mythological theme. ${ }^{68}$ Making concessions and granting strategic space to Russia or China, it is argued, would repeat the strategic and moral errors of British Prime Minister Neville Chamberlain, whose misguided diplomacy whetted the appetite of the predator Hitler, with disastrous results. In political life, many efforts at compromise or concession, or even the very act of talking to other states, have drawn this accusation. The appeasement slur traffics on a simplistic reading of Britain's complex mixture of rearmament, adjustment, and compromise in the deteriorating strategic environment of the late-1930s, builds its "timeless" argument on an atypical historical case, and ignores contrary cases in which prudent negotiation has succeeded (such as President Ronald Reagan's arms control talks with the General Secretary of the Soviet Union Mikhail Gorbachev). The slur also ignores cases in which inflexible escalation and the obsession with looking strong has led to overstretch and disaster (such as the Suez or Vietnam). ${ }^{69}$ In any event, a security regime is not the same thing as appeasement. It is an informal arrangement for bargaining, not a method for endlessly capitulating to one aggressor in the hope that it will be satiated. The concert carries with it the potential for counterbalancing against defectors and aggressive revisionist powers. 
There is an important and unsettled question of when precisely that negotiated order should see itself as threatened, and how much other states should actively counterbalance against one member. As Stephen Walt acknowledges, the United States, particularly in East Asia, faces the "Goldilocks" problem: how to get diplomacy "just right," neither too hot and antagonistic, thereby overburdening America's power, intensifying competition, and strengthening the hardliners of potentially adversary nations; nor "too cold," tempting its Asian partners either to escalate their own balancing behavior to dangerous levels, or even bandwagoning and creating precisely the kind of regional imbalance America fears. ${ }^{70}$ Where and how to draw such lines is the subject of the next and final section.

Even when allowing for the more incisive criticisms of Concert-Balance strategies, current conditions in some important respects would be conducive to such a strategic shift. Four converging trends make possible a sober reappraisal of America's position, at least toward a major retrenchment, and beyond that, a substantive shift in grand strategy. These factors are the reluctance of potential coalition members to take part in unbridled competition; the advantages of defending and deterring; transnational problems requiring collaborative efforts from great powers; and "hegemony fatigue" among the American people.

\section{The Lack of Appetite for Unbridled Competition.}

Two recent incidents suggest that when faced with the real prospect of it, states have little appetite for unbridled competition. The first was the abortive "quadrilateral" initiative of 2007, when U.S. Vice- 
President Cheney and Japanese Prime Minister Abe attempted to introduce India into the three-way dialogue of Australia, Japan, and the United States, leading to large joint military exercises. Beijing responded by issuing threats and formally protesting against what it regarded as a "small NATO" forming against it. In turn, India and Australia stepped back from the initiative, for fear of their counterbalancing efforts becoming a self-fulfilling prophecy that would turn China into a committed enemy. States that might have formed part of a coalition to contain another state (like China) instead balked at the prospect of a prematurely hard-line containment strategy, in effect choosing to develop their own military capabilities and develop bilateral security arrangements while waiting to see how China's peaceful rise would take shape. ${ }^{71}$ This suggests that the notion of a loose Western bloc existing as a counterbalancing force in being may be more fragile and reluctant than some expect. ${ }^{72}$ Australian Prime Minister Gillard has resumed this dialogue, but also insists that Canberra's goal is not to contain China. These two impulses - to accommodate a rising China while hedging against any threats it might pose - replicate the two principles of a Concert-Balance strategy.

The second revealing incident occurred in September 2010, when a Chinese trawler and a Japanese patrol ship collided near a contested island. After a Japanese patrol arrested the trawler captain, China demanded his release and an apology. China then halted the export of rare earth metals to Japan, threatening to cripple Japanese manufacturers, because Japan is reliant on these metals for making electronics and hybrid automobiles. Japan retaliated, promptly devaluing the yen in currency markets, dropping it 3 percent against the Chinese yuan. A destructive trade and currency 
war loomed. Both sides had a taste of a spiraling trade and currency war, and stepped back from the brink. ${ }^{73}$

These two incidents point to a broader issue, that in these mercantile times, international relations are too fragile for an all-out contest for supremacy between a U.S.-led coalition and China. States are demonstrably willing to compete within limits, to build up military capabilities, court allies and partners, make claims on scarce resources, and generally jostle for advantage. However, thus far, states have proven to be nervous when disputes escalate. Assembling a coalition to contain China too intensively could trigger crises, not least because China holds hundreds of billions of dollars in U.S. debt that could be dropped onto the market. America might find its allies distancing themselves when the hard costs of unmitigated competition focus their minds.

Thus, any viable U.S. strategy that a coalition would buy into must straddle the delicate balance between a self-defeating containment strategy and an excessive withdrawal leading to power vacuums. As Gordon defines the dilemma:

concede too much 'strategic space' to China too easily, and Beijing might simply assume weakness; form a coherent strategy for collectively balancing China and Beijing might be alienated and pushed into something akin to a new 'cold war'. ${ }^{74}$

This desire to balance competition with strategic cooperation is hardly a guarantee against future armed conflict. However, it does suggest that a middle-ground strategy is a better fit with the current diplomatic and economic pattern. 


\section{The Defender's Advantage.}

In addition to the reluctance of regional powers to engage in all-out competition, there is a military-strategic basis for a more collaborative order, namely, the relative difficulty and high costs of attack and coercion and the relative ease of defending and deterring. Historically, the dynamic competition between sword and shield is never-ending. As things stand, however, the defender's advantage, at least in theory, offers a sound reason for maintaining good political relations among the major states. ${ }^{75}$

The lethality, accuracy, and range of modern weapons, combined with the nuclear deterrent, make expansionism and military adventurism more costly and difficult than ever. ${ }^{76}$ Technological innovations since 1945, such as intercontinental missiles and nuclear weapons proliferation, clearly have a shrinking effect in terms of the projection of sheer offensive power, but strategically they also have a widening effect, making it very difficult to translate violence into military expansion against well-defended states. Nuclear weapons make the conquest of any state prohibitively expensive. The United States (and soon China) will have effective deterrent forces with secure second-strike capabilities. Defending states with secure second-strike ability to retaliate can devastate aggressor forces even with only a few punitive strikes. Nuclear weapons may not deter limited wars or allout nuclear exchange, and accident or misperception can take states to the brink of catastrophe. But they constrain the capacity of aggressors to expand. Other innovations such as ballistic and cruise missiles, satellites, and information technology confer on defending states a pre-targeting and long-range strike capability, 
enabling them to inflict severe damage on expeditionary forces operating from forward bases.

Several caveats are warranted here. The rising costs of war do not necessarily make major war obsolete, as miscalculation and accident can intervene. They do not guarantee that states will not attempt expansion, and do not rule out wars undertaken for reasons other than expansion. States may misperceive their environment. The objective properties of military technology do not ensure that states will accurately perceive those properties. Defenders with a theoretical advantage still may not use their capabilities optimally. Weapons can be ambiguous. Even those intended for primarily defensive purposes can appear to signal offensive intent. But in general, from the point of view of security communities with much to lose, armed conflict has rarely looked so unattractive and unrewarding. We may not have seen an end to interstate war, but we may be witnessing an end to conquest in the case of states possessing minimal defenses. If major states cannot conquer and cannot be conquered at tolerable cost and if they perceive their environment accurately enough, that is one good military-strategic reason to look for ways to limit competition and co-exist.

\section{Hegemony Fatigue.}

One trend that could work in favor of retrenchment and a change in grand strategy lies in domestic public opinion. Some primacists argue that the Wilsonian strain of muscular liberal crusading is the only authentic American tradition in the Republic's DNA. They object that American domestic opinion and strategic culture would obstruct any shift to a power-sharing strategy. The United States sees itself as exceptional. 
It is the only historical case of a truly unipolar world power. Others (like the Romans, Hapsburgs, Mongols, British, or French) in some measure were accustomed to co-existing with other powers. But the U.S. foreign policy establishment has been reared for decades on the Pax Americana, an unusually strong domestic cultural constraint. Some observers attribute a similar idealism among the American people, asking whether a more restrained strategy can retain the support of a democratic culture long drawn to viewing world politics as a Manichean struggle between good and evil. ${ }^{77}$ According to Robert Kagan, this tradition of messianic idealism makes America a "Neocon Nation" that is historically bound to an activist foreign policy. ${ }^{78}$

This is both ahistorical and misleading in the present. Consider recent empirical work by the likes of Dan Drezner and Christopher Preble into the gaps between elite and mass opinion on foreign policy, ${ }^{79}$ particularly in relation to the U.S. military-strategic posture and its diplomatic commitments abroad, the extent to which the United States should "burden shift," and the extent to which it should play the role of "sheriff" or "global cop." The evidence both analysts offer suggests that majority popular opinion is actually more averse to the current grand strategy of "leadership" than is often realized. Most Americans lean toward a focus on national interests narrowly conceived and toward priorities such as territorial and homeland security and regional hegemony, as well as protecting jobs and energy supplies. They support burden sharing onto other countries. Democracy promotion, human rights, or humanitarian peacekeeping - the agendas of active liberal internationalism - enthuses them substantially less. When it comes to the use of force, the Chicago Council on Global Affairs "found Americans think- 
ing about the use of force in the same way as offshore balancers." 80 They could be more receptive to change than elite opinion would be.

More recent opinion poll data support their findings. Recent polls suggest that Americans worry more about their jobs, their homes, their pensions, and health care than about export of American values or even dangers from abroad. ${ }^{81}$ Americans by substantial majorities favor burden sharing, believe the United States should not assume the role of preeminent world leader in solving international problems, and that it is playing "global cop" more than it should be. ${ }^{82}$ According to the Pew Research Center and the Council on Foreign Relations, the percentage of respondents who say the United States should "mind its own business internationally" has risen higher than at any point in 50 years. ${ }^{83}$ We do not have to embrace this absolute, isolationist message to recognize that these responses follow the logic that for America to do more at home, it will have to do less abroad. This is hardly surprising, given the interlocking factors of economic hardship and the lack of an obvious major adversary against which to mobilize. Emphatically, it is not unAmerican to prefer a strategy that retrenches some commitments, minimizes conflicts, redefines interests, shifts burdens, and frees up resources for domestic investment.

Public attitudes differ significantly from the broad penumbra of the foreign policy elite, including members of Congress, members of the executive branch, journalists and academics, lobbyists and interest groups, and the network of the most powerful foreign policy think tanks such as the Center for a New American Security and the Project for a New American Century. A diarchy of liberal internationalists 
and muscular nationalist hawks places all other ideas under the shadow of a Wilsonian tradition, in which the United States has no choice to secure itself but to dominate and convert the world. Members of this consensus regard themselves as different-contrast the unilateralist swagger of the Bush II era and the Obama administration's more consensual approach of stealth, charismatic uplift, and multilateralist modesty-but these are arguments about the techniques of American hegemony, not the wisdom of hegemony itself. Both major parties have marginalized contrary visions. Those who argue for a withdrawal from global primacy are to be found only on the political fringes of American conservatism and progressivism. Important pressure groups, such as the defense industry and the Taiwan lobby, reinforce the case for taking an adversarial rather than a collaborative stance toward Moscow or Beijing. So if the data on public opinion above are reliable, for a new grand strategy to take root, the most substantial shift would have to occur not in the minds of the American people but in Washington itself.

\section{PART III: MAKING IT WORK}

In the world of policy, the most pressing problem is not to debate the paradigm wars of international relations theory. It is calculating how to make a change in strategy work, both in terms of winning enough consent to sustain it and designing practical steps to operationalize it. This section goes beyond the muchdebated question of the wisdom of retrenchment, asking instead how to make it persuasive and workable, given its many imperfections. There are several competing models for a Concert-Balance strategy. Each of these models is based upon different assumptions 
and theoretical premises. This section considers these models, explaining the trade-offs they would entail. It then offers a menu of practical measures that strategic collaboration or a power-sharing grand bargain could include. The section's prime focus is on East Asia, given the growing perceived importance of the region, the focus Washington is placing on it, the apparent intensification of military-strategic rivalries already underway, and the dire consequences if the region were to erupt in the future.

I argue in this section that a new grand strategy should as far as possible aim to reconcile the need to retrench/realign resources and commitments, with the need to avoid, offset, or mitigate dangers flowing from partial or total withdrawal - primarily the unintended escalation of regional rivalries - and to retain an influential forward role in shaping this more multipolar world. To cover its bets in this regard, as well as retain domestic consent, it would be most prudent for the United States not to abandon the region but to find a more restrained presence in it, becoming either an "onshore" balancer, or an "over the horizon" one.

Defining America's frontiers, its core and periphery, is a perennial problem in its diplomatic history. It is never finally settled how to give geographical expression to its interests and to anticipating for what it would and would not bleed. These questions have nagged away at American policymakers ever since the Republic was founded. Secretary of State Dean Acheson's ill-fated attempt to delineate at the National Press Club in January 1950 an American sphere of commitment and defense line short of Formosa or Korea, shortly before the line was overruled by the Korean War and President Truman's expeditionary intervention into that peninsula, is only one of the 
most glaring cases. During that crisis, domestic politics, alliance bargaining, the pulse of the battlefield, and Truman's own rhetoric of a global war made geographic compromise hard to accept. ${ }^{84}$ Once America went beyond national self-defense into the open-ended pursuit of national security, its defense perimeter became unclear and potentially boundless, an endlessly shifting frontier. There is no certain way to "fix" America's interests definitively, even though ranking interests geographically remains an important (and difficult) exercise. This is why to achieve this difficult task, policymakers should look not only to the territorial and geographic disposition of U.S. power (bases, allies, and forward deployed military forces), but to the full range of ways to share power and forge a collaborative order (a refocusing onto common international threats such as nonproliferation, energy, and climate change; ramping up diplomatic communications between states and their militaries; creating a stable nuclear deterrence relationship; and neutralizing potential points of friction). If the ultimate goal is to secure the United States through an international regime of constructive collaboration while "hedging," or retaining the capacity to balance and compete, the issue must go beyond where the United States stations its forces, and look to the kind of diplomacy it links to its military posture.

\section{Strategic Choices: Three Models of Retrenchment.}

Hemispheric Pullback.

The most pure form of retrenchment would be a U.S. "hemispheric pullback" from East Asia and the Middle East, as well as completing the withdrawal from Europe. Having been a superpower with a glob- 
al military presence for 70 years, America would come home. In this model, the United States would extract its forward deployed military forces and terminate its formal alliance and permanent security relationships. It would restyle itself as an "offshore balancer," sharing power with growing and emerging states by virtue of its position as the dominant power in North America. It would reserve the right to intervene in extremis, namely, in interstate clashes as a balancer of last resort to thwart the challenge of any regional hegemon. It would retain the power projection capability to do so.

This approach trusts in the natural power balancing dynamic that would kick in with America's withdrawal. Its logic is that by doing less abroad, other states would do more to preserve the balance of power. This would free up resources to do more at home and divert valuable resources that could be invested more productively elsewhere, such as returning America's finances to solvency, investing in education or decaying infrastructure, and reducing America's dependence on foreign oil. This strategy assumes the essential security of America's own position. Supporters of this strategy see America as the most secure great power in modern times. With its distance and oceanic moats, its technologically sophisticated military, and its nuclear stockpile and intercontinental delivery systems, America's territorial integrity is assured. By extricating itself from commitments in the Persian Gulf, America would reduce its exposure to the blowback it has suffered as a result of its geopolitical presence, such as radical Islamist terrorism. This strategy is closely tied to a desire to restore the integrity of the Constitution and republican traditions. By abandoning military adventurism and dismantling its global hegemony and the national security state that comes 
with it, there would be less reason to compromise civil liberties and create an ever more powerful "imperial presidency." America could better influence the world through the power of its example, an idea that is also part of America's heritage of strategic ideas. According to its proponents, a withdrawn America would be more solvent, more secure, and more free.

The dilemmas this strategy would attract have already been laid out. Withdrawal could potentially jeopardize the credibility of the United States and its role as security guarantor, and it may be hard to balance credibly beyond arms transfers and finance. Without bases and permanent allies, active balancing would be more difficult militarily, requiring America to fight its way back into contested regions. The payoffs for this strategy would include a significantly reduced defense budget, a more free hand that would reduce the likelihood of America being in the center of geopolitical storms, a reduced probability of "moral hazards" through which America's patronage underwrites behavior antithetical to American ideals, and, in theory, an end to peripheral wars (such as Korea, Vietnam, or Iraq), and a reduced "national security state" with its constricting hold on constitutional liberties.

In terms of implementation and execution, proponents have not as yet offered in-depth blueprints. The bulk of their critique of U.S. grand strategy and their alternative statecraft is oriented toward the "offshore" rather than the "balancing" approaches. Christopher Layne and Benjamin Schwarz recently, and Eugene Gholz, Daryl G. Press, and Harvey M. Sapolsky earlier, have suggested an outline of the "hemispheric pullback" version. ${ }^{85}$ It would mean leaving NATO and the retraction of forces from Europe, shifting to the Euro- 
pean Union (EU) responsibility for its own defense. It would mean ending the treaty of mutual security with Japan and withdrawing militarily from South Korea. It would mean removing most U.S. forces from the Gulf except for its naval presence in the straits of Hormuz. Not only does this strategy assume that in all these regions, a natural dynamic of power balancing and counterbalancing would arise with America's withdrawal; it also assumes and accepts that there will be nuclear proliferation. Compared to competing strategic visions, this approach is relatively relaxed about the spread of nuclear weapons to states like Japan, Korea, and (hypothetically) Germany, though not about proliferation to hostile states or nonstate actors. Proponents of this strategy would even be open to assisting these states with building a second-strike nuclear deterrent and with command-and-control of their stockpile. In addition, the strategy would shift to the likes of India, Japan, Russia, and Korea the full burden of balancing China in its rapid rise, and balancing each other, except in the event of an all-out bid for expansion by one state. It would have America adopt a far more restrained, conciliatory, and nonconfrontational relationship with Beijing. This would entail abandoning attempts to promote democracy in China and declaring that the Taiwan question is a "purely internal Chinese matter." It would mean cultivating a similar relationship with Moscow, partly out of recognition that Washington cannot transform Russia into a market democracy at will, and partly out of reliance on Russia as a pivotal player in the power balancing to be done against a future EU superstate, an ascendant China or in the Persian Gulf. All this would be accompanied by a significant reduction in America's nuclear arsenal, but with the development and deployment of 
a missile defense system. Both these measures would be designed to erect a shield against "rogue" elements armed with long-range missiles or nuclear weapons, while simultaneously reassuring other powers that America does not pose a threat. America would avoid the use of land power as much as possible, relying heavily on naval and air power and capitalizing on America's advantages of accurate, standoff firepower and its intelligence, surveillance, and reconnaissance capabilities.

In terms of implementation and pacing, advocates of withdrawal insist it should be done carefully and gradually, so that an orderly and well-sequenced withdrawal would give regional players time to adjust. America would assist the transition through arms sales and technology transfers. It would still conduct regular joint exercises and pursue close military relationships with Europeans, Japanese, Indians, and Russians. The United States would seek a network of basing rights should it need to reinsert itself in the future.

The hemispheric pullback strategy makes assumptions founded on a well-articulated neorealist theory. Its bedrock point is well made, that the United States is essentially a materially secure state, not easily threatened existentially by other rising states. Because it can remain secure in its own neighborhood, it can afford to retrench and hand over responsibility to others. The strategy's logic, as Barry Posen puts it, is to pursue "a coherent, integrated and patient effort to encourage its long-term wards to look after themselves" - if others do more, it saves U.S. resources, and prompts them to "think harder about their choices." At the same time, this will require great finesse and gradualism. "A governing rule should be not to shift positions so rapidly 
or decisively that altered regional politics open windows of vulnerability or opportunity that either tempt or compel military action." 86

There are nontrivial risks that a "hemispheric pullback" would run if its expectations turn out to be wrong. Allowing for regional competition and balancing may result in intensifying security competitions and, according to offshore balancing theorists, may well involve nuclear proliferation. These developments may well not be as tolerable to the United States as advocates think. For obvious historical reasons, it is not clear how Washington could create more peaceful relations with China while simultaneously assisting a Japanese nuclear weapons program. The development of a Japanese bomb in itself, even one undertaken for entirely defensive purposes, would likely be perceived in Beijing as a serious threat and a provocation. Even in an era in which states are reluctant to engage in unbridled competition, that could constitute a "red line" for Beijing, triggering preventive war. America would probably survive a Sino-Japanese war, but a clash between two of its major trading partners would mean that the benefits of withdrawal in that region may be negated by its costs.

Conceptually, offshore balancing is not the same as isolationism. But it may well appear to be the same thing, and this perception could have consequences. It would conceivably be difficult to persuade allies and partners that by withdrawing, the United States would credibly act as a balancer and have their back when things become dangerous. It is also not clear how easily Washington could secure basing rights without a credible military-strategic presence signaling commitment and reassurance. A purely "offshore" strategy does offer a reduction in the costs that come with 
American primacy, as it effectively hands over the costs of self-defense to others. It reduces the chance of being unwittingly entangled in a regional crisis. On the other hand, it also relies strongly on the balancing power of others. In the scenario in which the balancing of others fails, where a serious hostile imbalance does occur, whether in the Gulf or Asia, and where a withdrawn United States attempts to intervene and rebalance against a rising adversary, the costs of remobilizing and "breaking in" could be steep, measured in blood or treasure.

\section{Over-the-Horizon Balancer.}

The United States could opt for an alternative version of Concert-Balance, as an "over-the-horizon" force. In this model, the United States would seek to accommodate the rise of emerging states to a degree. But unlike the model of total withdrawal, it would also maintain its presence in the wider neighborhood as a basis for potential intervention and as a way of constraining and deterring the rise of any one hegemon and limiting the fallout flowing from the new multipolarity. America would retain the pillars of its strategic position, maintaining NATO in the EuroAtlantic world and its alliance with Japan. It would recognize that the process of balancing may be slow, states may miscalculate, and nuclear deterrence could fail. The United States would be in a better position to "balance" - while still reducing its footprint-if it remained engaged.

Balancing happens, but it happens earlier and more easily with a leader. Nuclear weapons deter, but why not place the weight of U.S. strategic nuclear forces 
behind the status quo powers, just to simplify the calculations of the ambitious? ${ }^{87}$

Thus, the onshore version would be less likely to insulate the United States from a major interstate war (a payoff highly valued by "offshore" theorists), but more likely to retain a basis for influence and deterrence, and a position of power-projection strength.

Several commentators advocate some version of this strategy of making space without a complete withdrawal. ${ }^{88}$ On the basis that Washington ought not to go on regarding the Pacific as an American lake, these visions call for a new power-sharing settlement. For Walter McDougall, ${ }^{89}$ it would be akin to the Naval Conference of 1921-22, claiming that this is more feasible because there is no power poised to seize regional naval hegemony like Japan in the interwar years. America and China would essentially concede to one another "zones of control" that both should not contest except when under attack. The main problem would be defining where to draw this line. Chinese strategists have identified a first island chain, of Taiwan, the Korean peninsula, and the South China Sea, leaving the Philippines, Malaysia, Indonesia, and further points east in America's orbit. The United States could pull back further to a contracted "outer chain" of islands, perhaps covering Japan, Guam, and Okinawa, as part of a defensive perimeter stretching out from Alaska and Hawaii.

To execute this strategy would require some tough choices. To have any chance of successfully persuading Beijing to accept limits on its expansion to a defined zone of control, it would mean allowing for a process of Finlandization; that is, creating a new power balance in which small neighboring countries 
feel strongly influenced to accommodate their policies to the larger one, becoming tributary states at least in the realm of foreign policy. This would mean conceding any claims or involvement over Taiwan at minimum, possibly in the form of a gradual easing of commitment. It could even mean withdrawing gradually from South Korea and distancing from the Philippines as well. But above all, Taiwan goes to the heart of the Washington-Beijing relationship. China regards it as part of its territory and aims at unification at most, or predominance and incorporating it into its orbit at least. China has declared that it will respond with force to any unilateral declaration of independence. For the United States, Taiwan represents precisely the kind of second-order commitment that could become a basis for escalation and war, but also one which could be liquidated in order to purchase a more stable coexistence.

How well could America live with uncontested Chinese dominance of its "near abroad"? According to advocates of this strategy, a superior American navy with its friends beyond the first island chain, and an Indian navy and friends beyond the Straits of Malacca, would be positioned to "keep China honest." Critics claim that this would be the equivalent of a "Munich moment" of disastrous appeasement. Taiwan represents the most difficult and ideologically unsettling aspect of sharing power. Not to put too fine a point on it, but even if this is done as a gradual easing of the commitment, it would amount to an abandonment of Taipai by Washington. Would this moral and strategic compromise be worth it in order to purchase a wider regional peace? There is at least a strong case that the fate of millions in Asia and the United States should not be held hostage to the question of China's 
sovereignty claims to a territory. In addition, accepting the movement of Taiwan into China's orbit would be in accord with Taiwan's recent "second détente" and its conscious policy of Finlandization, or making concessions to a larger neighbor in order to preserve a degree of independence and enjoy the benefits and added security that closer ties would bring. Far from betraying an ally, conceding this change would be in line with that ally's own democratic will, its preferred strategy of demilitarizing the Taiwan Straits issue. This may help to dampen China's sense of insecurity, which has fueled its own military buildup by removing a potential strategic menace from its East Asian shipping lanes. It may help purchase Chinese cooperation in other areas where both Washington and Beijing have common interests, from international finance to nonproliferation. ${ }^{90}$ With regard to the "Munich" charge, it is not clear that Beijing has an appetite for limitless expansion, or that China's strategy of "peaceful rise" is comparable to that of the Third Reich. Even if it is, now or in the future, conditions are not promising for a would-be conqueror. East Asia is not a power vacuum open to the predations of a single aggressor like Nazi Germany or Imperial Japan, but a region crowded with states developing their own formidable defensive maritime-air capabilities to deter and respond to one power's adventurism.

In addition to persuading a domestic audience, the most problematic aspect of a concession over Taiwan would be how to fit it into a broader strategic realignment. Would it endanger America's credibility in the eyes of its allies? Credibility is an ambiguous diplomatic commodity. Scholars are still at odds over what generates it and what threatens it. It may be that credibility is not threatened, and can even be bolstered, 
by withdrawing from a peripheral commitment and refocusing efforts on more tightly defined interests. ${ }^{91}$ But if this is wrong, and if credibility can be endangered by concessions over Taiwan, it could be argued that the United States should guard against this by reinforcing its commitments to the likes of Japan and South Korea in the form of joint military exercises and a shift to a more air-maritime presence. This, however, would place limits on the retrenchment process and the benefits that would flow.

What of the Gulf? The lion's share of this monograph has focused on East Asia and China, as that may be the nexus for world politics of tomorrow, and where America's most likely and most powerful challenger may arise. But in the Middle East, the United States also faces the issue of how to get it "just right," steering a course between destabilizing withdrawal and the status quo with its costs (the direct link between America's geopolitical approach to Gulf regimes and the global brand of Islamist terrorism), and its potential future dangers (the simultaneous empowerment of and clash with Iran).

America's main security interests in the Gulf are the flow of oil and, because of the resource bounty that the Gulf generates, the prevention of any single state from dominating it. This danger is less pronounced than in the past: There is not one single global power, such as the Soviet Union, that threatens direct territorial conquest of the region and could harness its resources to empower itself and potentially threaten or blackmail others. Nevertheless, the United States also surely has an interest in the security of the oil market as an important part of the world economy, and given that most states in the region are non-nuclear at present, one power's bid for hegemony is remote but not impossible. 
As America withdraws its troops from Iraq, balancing by others is already evident, suggesting that if America does less, others may do more.

Tehran's stated intention to project its interests regionally through military or paramilitary forces has made Iran its own worst enemy. Iran's neighbours are choosing to balance against the Islamic Republic rather than fall in line behind its leadership. In 2006, Iran's favourability rating in Arab countries stood at nearly 80 percent; today, it is under 30 percent. Like China's neighbours in East Asia, the Gulf states have responded to Iran's belligerence by participating in an emerging regional security arrangement with the United States, which includes advanced conventional weapons sales, missile defences, intelligence sharing, and joint military exercises, all of which have further isolated Iran. ${ }^{92}$

Again, the most prudent course may be to act in an over-the-horizon capacity, finding a middle ground between excessive geopolitical entanglement that attracts blowback, and being missing in action in the event of an aggressor threatening the balance. America would thus have a difficult balancing act, being capable enough to intervene from afar as an antihegemonial spoiler, for example, in turning back Saddam Hussein's invasion of Kuwait in 1990-91, while removed to bases outside the region with its troops and pilots "off the ground."

\section{Other Paths to a Concert.}

The above two models are territorial at their core. If sharing power is their goal, their method is to make room literally for an expanding China. But policymakers should look not only to the territorial disposition of U.S. power (bases, allies, and forward deployed 
military forces), but to the full range of ways to share power and forge a collaborative order. Apart from contracting its sphere of influence physically, the United States could look to a range of other creative power-sharing methods to give China recognition as a serious regional heavyweight in its own right, while still retaining the capacity to deter and respond with force to any threat to its interests or allies. These measures could supplement a territorial withdrawal and a shift to a "lighter footprint" presence. They could also be a substitute, so that if the status quo remains territorially, the United States could at least blunt its worst features.

One achievable step in this direction would be Joint U.S.-China military exercises and the enhancement of military-to-military communications. Admiral Sam Locklear, U.S. Commander Pacific Forces, recently spoke in support of calls by Indonesian President Susilo Bambang Yudhoyono for joint exercises.

We should look for opportunities to bring China into these multilateral forums, so we can ensure that they can fulfil a role... [China is] a growing regional power, certainly an economic power, and I think it's in all our best interests to ensure that we allow them to be properly integrated in that security environment. ${ }^{93}$

This would be useful for confidence building and preventing a security dilemma. It would also be helpful as a measure of crisis management. Regular interactions and closer communications between both the United States and China might reduce chances of misunderstandings or miscalculations. Consider the incident in 2006, in which, after a Chinese submarine had a close encounter with a U.S. battle group in the Pacific, military commanders from both sides had 
no method for reaching each other in an emergency, resulting in a 24-hour delay between Pacific Commander Admiral Fallon's communication and his counterpart's response. ${ }^{94}$

If the Sino-U.S. relationship is to go beyond balancing and become a concert or a "regime" in which both sides forego potential advantages in order to limit competition, one opportunity for mutual (though watchful) restraint lies in the area of space arms control. ${ }^{95}$ China and Russia have called for a treaty to prevent a space arms race. As it happens, the United States and other space-faring countries are now negotiating a new space arms control initiative. ${ }^{96}$

Critics frame this issue as a question of the United States surrendering its military advantages and paying a heavy price for dubious gains. But the United States has a strong interest in preventing an astral military competition. As things stand, it relies heavily on space satellites for reconnaissance, surveillance, communications, and intelligence to sustain its military dominance. A more contested geography could jeopardize this status quo if it featured the development of asymmetric capabilities by America's rivals, as well as increasing amounts of fallout from the arms race, such as debris from anti-satellite missile tests. If the United States has more to lose in an action-reaction antisatellite arms race, it could still be possible to hedge against future assaults on American satellites through alternative means, such as hardening the defenses of satellites and ground stations and maintaining deterrence through the ability to strike adversary's ground stations, links, and missile launch facilities. ${ }^{97}$

For this to succeed, obviously other states would have to make concessions, for example, giving ground on America's wish to prohibit terrestrial anti-satellite 
systems. There would have to be sufficient verifiability and transparency. As with security regimes generally, an arms control agreement of this kind would rely greatly on a roughly equal commitment to sustain it. It would be vulnerable to mistrust and to any one side's decision to cheat or pre-empt what it perceives as the inevitable cheating of others. Mutual restraint in space would be fatally undermined if one side turned fatalist, believing that the world is inherently predatory and conflictual and thus, through a self-fulfilling prophecy, destroyed the effort. Therefore, an arms control initiative would be difficult to sustain. But it could also be a prudent way to both forge a collaborative set of relationships while actually preserving a U.S. military advantage. By trading unrestricted military freedom (and an ever greater offensive military advantage), the United States might be able to create a more benign, less contested domain. The alternativean all-out race for space domination-may be more crudely satisfying, but an astral arms race could also lead to greater threat to U.S. space satellites.

A successful concert needs a level of stability. One indispensible element would be for powers such as Washington, Beijing, and Moscow to take steps to stabilize their nuclear relationships. In addition to the size of arsenals, the stability of the relationship between powers seeking to deter one another is paramount. Two areas of self-restraint would be prudent: a halt to NATO expansion, and the abandonment of Ballistic Missile Defense. A little imagination shows just how threatening the expansion of NATO and the pursuit of a missile shield have been. George Kennan warned wisely in 1997 that NATO enlargement would be "the most fateful error of American policy in the entire post-Cold War era" and would antagonize Russia and 
inflame its "nationalistic, anti-western and militaristic tendencies." 98 If Russia or China made military alliances with states bordering the United States; if they subdivided America's sphere into a series of military commands; if they erected a shield that threatened to make it impossible for America to retaliate against a nuclear first strike; if they could operate battle carrier groups within range of America's borders-all while declaring the inevitable triumph of their own ideologies - the United States would obviously feel that its legitimate security interests were threatened. In response, the United States would take measures to counter these threats, and the relationships among the three nations would quickly break down. America is hardly responsible for all of China's behavior, just as NATO is hardly responsible for all of Moscow's behavior. But the regional supremacism, muscle flexing, and coercion practiced by both does flow in part from fear. Russia's support for secessionists and its war in Georgia in 2008 took place in an atmosphere in which Russia was continually humiliated, threatened, and provoked with the historically displeasing pattern of Western power marching into its sphere.

With respect to the nuclear dimension of ChineseU.S. relations, there is a worrying dynamic unfolding at present. ${ }^{99}$ Beijing's capabilities are currently modest, with only a handful of nuclear weapons able to reach U.S. shores. It fears that the United States could devastate its nuclear forces with a first strike, and that America's missile shield would then prevent retaliation, notwithstanding American assurances that its limited ballistic missile shield is not directed against China. China's fears may be growing, especially given that Washington now plans to improve its missile defense systems in the Asia-Pacific area. In theory, 
if China's fears were realized, that could mean the United States negating China's deterrent and leaving it open to nuclear blackmail or worse. It therefore now pursues a survivable second-strike capability with intercontinental reach. However, in turn, this concerns Washington, as it sees China's nuclear modernization as possibly a threatening move by a revisionist power. Once China obtains a relatively secure second-strike capability, the two states have a choice. They can pursue open-ended antagonism and compete with an eventual nuclear war in mind, with the United States attempting to pursue the supposed absolute security that a shield would bring. Or they could attempt to negotiate an arms-control agreement and acknowledge one another as nuclear peers, as well as open up a general framework for negotiation. At that point, rather than comparing the relative strengths of their stockpiles, the stability of the relationship would be critical. For acknowledging the legitimacy of China's nuclear deterrent and abandoning the further development of an expensive and difficult missile shield, the United States would ask that China forego any further expansion of its nuclear weapons program. This would not require either side to be naively utopian in its hopes. "Trust, but verify" would still be the watchword.

None of this means that America must surrender its forward deployed military presence and its capacity to hedge against mischief. It is no guarantee that the relaxation of military competition would be rewarded by reciprocal restraint from Russia or China. But it is surely worth a try. It does mean that America can afford to practice self-restraint in areas where the pursuit of absolute security has perverse results. The United States already possesses a secure second-strike 
capability with which it could respond to any attack with overwhelming force. From this strong position, America could avert risking a spiral of mistrust.

There are several other areas that, taken as a whole, could cumulatively form a basis for confidence-building and forging a concert. Some would be positive areas of common action; others would be measures of self-restraint. One positive area is the nuclear fusion project ITER (originally known as International Thermonuclear Experimental Reactor), which is part of the joint pursuit of a common nonpolluting, renewable energy source. ${ }^{100}$ It already involves the major states discussed herein, as well as South Korea. In an era of resource scarcity, population growth, and an increasing need for sustainable energy, this is an obvious area of common interest that will probably become more urgent. Weapons nonproliferation is another common interest, and an effort is already underway in the shape of the renewed international commitment to secure loose nuclear materials in the territories of the former Soviet Union.

In addition to aiming for progress in these areas, the deeper purpose would be to extract a broader joint cooperation from the discrete measures. For example, by making concessions over Taiwan, missile defense, and NATO expansion, the United States would have a better chance of securing tighter Russian and Chinese support for preventing nuclear proliferation in Iran and even hammering out a grand bargain, through which Iran is granted its Non-Proliferation Treaty (NPT) rights to enrich uranium for civilian purposes in return for inspections and verification. Again, nothing is certain, and American restraint may not attract reciprocal restraint. It would at least be prudent to create opportunities and incentives for other powers to 
cooperate more and compete less. Should other states reject or resist these initiatives and choose unbridled competition, they would have much to lose. In that event, America would probably be in a stronger position not only militarily but diplomatically, as the responsible superpower that offered others the chance for a more collaborative world order.

Though the debate about competing grand strategies may often become theoretical, to make a more collaborative grand strategy succeed would take a great deal of hard diplomatic work. Critics may claim that Concert-Balance strategies are passive. But they would actually demand a stepped-up diplomacy and greater levels of multilateral engagement and communication, and all of that would need greater investment and resources. This would pose an added challenge to a nation accustomed to primacy and the diplomacy of an American Century in which Washington urges other states to play by American rules. If we are seeing the coming of a more multipolar world, that world would be a more negotiated universe, characterized increasingly by compromise and bargaining. If we are seeing a world of increased "balancing" and "hedging" by rising states, that too will require greater levels of diplomatic dialogue to prevent competition spinning out of control. In this respect, a more collaborative strategy would be more active than the current one, rather than less.

The success of the 19th-century concert of Europe partly rested on the refocusing of states upon common threats, in their case, a common fear of the interlocking forces of revolution and major war. Are there sufficiently powerful common interests and threats to those interests that could be the foundation for a modern-day concert? There are transnational prob- 
lems that, if placed at the center of relations, could form a "glue": weapons nonproliferation, energy security and supply, the security of the sea lanes, and resilience against planetary disasters. Above all, there would be the most potentially powerful pacifying force of all, the common reluctance to engage in unmitigated competition.

\section{CONCLUSION}

As this monograph has argued, given the possible future insolvency of America's current grand strategy, a program of retrenchment and a new strategy based on an acceptance of multipolarity and the limits of power is prudent. There is scope for such a shift. The convergence of several trends-transnational problems needing collaborative efforts, reluctance to engage in unbridled competition, the military-strategic advantages (for the moment) enjoyed by defenders, and "hegemony fatigue" among the American people-means that an opportunity exists internationally and at home for a shift to a new strategy. The ultimate aim of a new, more modest, and more collaborative grand strategy should not be to dismantle America's power, but to make it last longer. It would attempt a historically difficult task, that of forging a collaborative and mostly peaceful world order, while preparing for a more dangerous one, where the United States could deter and respond to would-be aggressors.

But a Concert-Balance strategy will still need to deal with several potential dilemmas. These include the difficulty of reconciling competitive balancing with cooperative concerts, the limits of balancing without a forward-reaching onshore military capability, the 
possible unanticipated consequences such as a spiral in regional power competition or the emergence of blocs (such as a Chinese East Asia or an Iranian Gulf), and the hard task of building domestic support for a strategy that voluntarily abdicates world leadership. These difficulties can be mitigated, not least through creative measures such as the ones suggest above. But they must be met with pragmatic and gradual implementation as well as elegant theorizing, and the need to avoid swapping one ironclad, doctrinaire grand strategy for another.

The move to a different strategy in all of its competing versions would carry serious implications for America's land forces. A "Western Hemispheric" version of a new strategy would probably see America's land commitments retracted back to an outer island chain, gradually drawing down troops from South Korea, reducing the size of America's forwarddeployed land forces generally, and positioning them as a more withdrawn and reserve force in the outer island chain. At the extreme end of the spectrum, the purely continental version promoted by some offshore balancing theorists, U.S. land forces would take on the role of being primarily homeland defenders. They would ideally retain the capability for expeditionary warfare beyond the water's edge. As argued above, this would conceivably lower costs but pose considerable difficulties for America's land, sea, and air forces should they need to fight their way back in to a thickly defended theater abroad.

The above judgments and proposals may or may not be flawed. But even if they are ill-conceived, there is a more important point that should inform the debate. It is that alternatives to Primacy should identify the difficult trade-offs involved in any grand strate- 
gic shift, and should anticipate worst-case scenarios in the event that their underlying premises turn out to be mistaken. The guiding logic should be to steer carefully between the danger of the U.S. presence in a neighborhood of growing giants leading to costly rivalries and confrontations, and a U.S. retreat that could create dangerous power vacuums and destabilize regions. It is time to weigh seriously the dilemmas and potential benefits a new strategy would present. Only then can we grasp what it means, and what it costs.

\section{ENDNOTES}

1. Jeremi Suri, "Where are the Kissingers?" Global Brief, 2010, pp. 32-33; Edward Luttwak, "Take me Back to Constantinople: How Byzantium, not Rome, can Preserve the Pax Americana," Foreign Policy, November/December 2009; The Grand Strategy of the Byzantine Empire, Cambridge, MA: Harvard University Press, 2009; Robert E. Hunter, "A New Grand Strategy for the United States," Testimony presented before the House Armed Services Committee, Subcommittee on Oversight and Investigations on July 31, 2008, Santa Monica, CA: RAND Corporation, July 2008; Daniel W. Drezner, "The Grandest Strategy of Them All," The Washington Post, December 17, 2006; Jeffrey V. Gardner, Evolving U.S. Grand Strategies: How Administrations Have Approached the National Security Strategy Report, Raleigh, NC: Lulu, 2004; Gary Hart, The Fourth Power: An Essay Concerning a Grand Strategy for the United States in the 21st Century, New York: Oxford University Press, 2004; Robert J. Art, A Grand Strategy for America, Ithaca, NY: Cornell University Press, 2003; Barry R. Posen, "The Struggle Against Terrorism: Grand Strategy, Strategy and Tactics," International Security, Vol. 26, No. 3, 2001/2002, pp. 39-55; G. John Ikenberry, "American Grand Strategy in the Age of Terror," Survival, Vol. 43, No. 4, Winter 2001-02, pp. 19-34.

2. I derive this formula from Posen, The Sources of Military Doctrine: France, Britain, and Germany between the World Wars, Ithaca, NY: Cornell University Press, 1984, p. 13; Richard K. Betts, “Is Strategy an Illusion?" International Security, Vol. 25, No. 2, 2000, 
pp. 5-50, especially p. 6; Paul M. Kennedy, ed., Grand Strategies in War and Peace, New Haven, CT: Yale University Press, 1991.

3. See Colin Gray's development of this point, The Strategy Bridge: Theory for Practice, Oxford, UK: Oxford University Press, 2010.

4. "A Security Policy for Postwar America," March 8, 1945, in the Hoover Institution of War, Peace and Revolution, Stanford University, CA, Albert C. Wedemeyer Papers, Box 90, Folder 5, "Politics and Government," discussed in Melvyn Leffler, A Preponderance of Power: National Security, the Truman Administration, and the Cold War, Stanford, CA: Stanford University Press, 1992, p. 11.

5. See Colin S. Gray, "Harry S. Truman and the Forming of American Grand Strategy in the Cold War, 1945-1953," in Williamson Murray, Richard Hart Sinnreich, and James Lacey, eds., The Shaping of Grand Strategy: Policy, Diplomacy and War, Cambridge, MA: Cambridge University Press, 2011, pp. 210-253.

6. On the issue of continuity and discontinuity in U.S. grand strategic history, see Eric Hamilton, "Redefining and Rethinking U.S. 'Grand Strategy' since World War II: Some HistoricalInstitutional Insights," International Studies Association Conference, San Diego, CA, April 1-4, 2012; Melvyn Leffler, "9/11 and American Foreign Policy," Diplomatic History, Vol. 29, No. 3, 2005, pp. 395-413.

7. Phrase borrowed from Joseph Joffe, Uberpower: The Imperial Temptation of America, New York: W. W. Norton, 2006, p. 137.

8. Michael Lind, "State of Denial," Salon, September 13, 2011.

9. “Excerpts from Pentagon's Plan: 'Prevent the Re-emergence of a New Rival'," The New York Times, March 8, 1992.

10. Anthony Lake, "From Containment to Enlargement," U.S. Department of State Dispatch, Vol. 4, No. 39, September 27, 1993, pp. 658-664; as John Lewis Gaddis relates, “. . . President Clinton assured an aide in 1994 that Roosevelt and Truman had gotten along fine without grand strategies. They'd just made it up as 
they went along, and he didn't see why he couldn't do the same." Lecture, "What is Grand Strategy?" February 26, 2009, Duke University, Durham, NC. On the continuity of strategy through the Clinton administration, see Christopher Layne, "Take Up the Slack: Is Grand Strategy Governed by Ambition or Politics?" Weekly Standard, Vol. 17, No. 27, March 26, 2012.

11. Robert J. Lieber, Power and Willpower in the American Future: Why the United States is not Destined to Decline, Cambridge, MA: Cambridge University Press, 2012; "Falling Upwards: Declinism, the Box Set," World Affairs, Summer 2008; Edward Luce, Time to Start Thinking: America in the Age of Descent, New York: Atlantic Monthly Press, 2012; Robert Kagan, The World America Made, New York: Alfred A. Knopf, 2012; Carla Norloff, America's Global Advantage: U.S. Hegemony and International Cooperation, Cambridge, MA: Cambridge University Press, 2010; Christopher Layne, "Graceful Decline: The End of the Pax Americana," American Conservative, Vol. 9, No. 5, 2010, pp. 30-31; Joseph Joffe, "The Default Power," The New York Times, August 20, 2009; Fareed Zakaria, "The Future of American Power," Foreign Affairs, Vol. 87, No. 3, 2008, pp. 18-43.

12. According to one estimate, looking out to 2025, there will be an "unprecedented shift in relative wealth and economic power roughly from West to East." Global Trends 2025: A Transformed World, Washington DC: U.S. Government Printing Office, 2008 , p. iv.

13. Robert Kaplan, Monsoon: The Indian Ocean and the Future of American Power, New York: Random House, 2011.

14. On theories of decline, their poor record of prediction, and the ideologies on which they can be premised, see Adam Gopnik, "Decline, Fall, Rinse, Repeat: Is America Going Down?" The New Yorker, September 12, 2011, pp. 40-47; Arthur Herman, The Idea of Decline in Western History, New York: Free Press, 1997.

15. According to the Congressional Budget Office, the ratio of U.S. Government debt to gross domestic product will be 100 percent by 2020 , a level economists typically regard as a critical indicator of possible default. See Congressional Budget Office, The Budget and Economic Outlook, Fiscal Years 2010 to 2020, Washington, DC: Government Printing Office, 2010. 
16. Greg Miller, "Global Economic Crisis Called Biggest U.S. Security Threat," The Los Angeles Times, February 13, 2009; David Ignatius, "How Debt Imperils National Security," The Washington Post, May 23, 2010; Ed O’Keefe, "Mullen: Despite Deal, Debt Still Poses the Biggest Threat to U.S. National Security," Checkpoint Washington, August 2, 2011, available from www.washingtonpost. com/blogs/checkpoint-washington/post/mullen-despite-deal-debt-still-arisk-to-national-security/2011/08/02/gIQAhSr2oI_blog.html.

17. Ian Bremmer, Every Nation for Itself: Winners and Losers in a G-Zero World, London, UK: Portfolio, 2012, pp. 11-12.

18. As Niall Ferguson argues in "Complexity and Collapse: Empires on the Edge of Chaos," Foreign Affairs, 2010, pp. 18-32.

19. Walter Lippmann, U.S. Foreign Policy: Shield of the Republic, Boston, MA: Little, Brown \& Co., 1943, pp. 6-7.

20. On typologies of self-defeating behavior, see Charles A. Kupchan, The Vulnerability of Empire, Ithaca, NY: Cornell University Press, 1994, pp. 3-8.

21. As argued by Joseph M. Parent and Paul K. Macdonald, "The Wisdom of Retrenchment: America Must Cut Back to Move Forward," Foreign Affairs, Vol. 90, No. 6, 2011, pp. 32-47, especially p. 40.

22. As Robert Pape suggests in "Empire Falls," The National Interest, Vol. 99, 2009, pp. 21-34.

23. On the relationship between America's support for the Gulf "apostate regimes" and the evolution of al-Qaeda's assault on the "far enemy," see Peter L. Bergen, The Longest War: The Enduring Conflict between America and Al Qaeda, New York: Simon \& Schuster 2011, pp. 18-21; Rohan Gunaratna, Inside Al Qaeda: Global Network of Terror, New York: Columbia University Press, 2002, p. 45; Max Abrahms, "Al-Qaeda's Scorecard: A Progress Report on al-Qaeda's Objectives," Studies in Conflict and Terrorism, Vol. 29, No. 4, 2006, pp. 509-529.

24. This definition is drawn from Joseph M. Parent and Paul K. MacDonald, "Graceful Decline? The Surprising Success of 
Great Power Retrenchment," International Security, Vol. 35, No. 4, 2011, pp. 7-44.

25. On this issue, see Henry Kissinger, "The Future of U.S.Chinese Relations: Conflict is a Choice, Not a Necessity," Foreign Affairs, Vol. 91, No. 2, 2012, pp. 44-55; Charles A. Kupchan, How Enemies Become Friends: The Sources of Stable Peace, Princeton, NJ: Princeton University Press, 2010.

26. For a critique of power transition theory, see Richard Ned Lebow and Benjamin Valentino, "Lost in Transition: A Critical Analysis of Power Transition Theory," International Relations, Vol. 23, No. 3, 2009, pp. 9-410.

27. "Could Asia Really Go to War Over These? The Bickering Over Islands is a Serious Threat to the Region's Peace and Prosperity," The Economist, September 22, 2012; Brian Spegele, "China Adds Aircraft Carrier to its Navy," The Wall Street Journal, September 26, 2012.

28. As Tang Shiping argues in "From Offensive to Defensive Realism: A Social Evolutionary Interpretation of China's Security Strategy," in Robert S. Ross and Zhu Feng, eds., China's Ascent: Power, Security and the Future of International Politics, Ithaca, NY: Cornell University Press, 2008, pp. 141-162, especially p. 153.

29. Gary Roughead, James Conway, and Thad Allen, A Cooperative Strategy for 21st Century Seapower, U.S. Government, Kissimmee, FL: Signalman, 2008.

30. Barry R. Posen and Andrew L. Ross, "Competing Visions for U.S. Grand Strategy," International Security, Vol. 21, No. 3, 1996/7, pp. 5-53.

31. Stephen Biddle, American Grand Strategy after 9/11: An Assessment, Carlisle, PA: U.S. Army War College, Strategic Studies Institute, April 2005; John Lewis Gaddis, Strategies of Containment: A Critical Appraisal of American National Security Policy during the Cold War, Oxford, UK: Oxford University Press, 1982.

32. For a helpful discussion of balancing strategies and their precedents, see Daniel Trombly, "Unpacking Isolationism 
and Offshore Balancing," Fear, Honour and Interest, October 20, 2011, available from fearhonorinterest.wordpress.com/tag/offshorebalancing/.

33. Michael Lind, "A Concert-Balance Strategy for a Multipolar World," Parameters, Vol. 38, 2008, pp. 48-60; Hugh White, "The Obama Doctrine: The U.S. Plan to Take on China Recalls Harry Truman's Containment of the Soviet Union," The Wall Street Journal, November 25, 2011; Power Shift: Australia's Future between Washington and Beijing, Quarterly Essay Series, Vol. 39, 2010; Steven Van Evera, "A Farewell to Geopolitics," in Melvyn Leffer and Jeffrey W. Legro, eds., To Lead the World: American Strategy after the Bush Doctrine, Oxford, UK: Oxford University Press, 2008, pp. 11-30; Nina Hachigian and Mona Sutphen, The Next American Century: How the U.S. Can Thrive as Other Powers Rise, New York: Simon \& Schuster, 2008.

34. Hugh White, The China Choice: Why America Should Share Power, Collingwood, Ontario, Canada: Black Ink, 2012, pp. 128155; Coral Bell, Living with Giants: Finding Australia's Place in a More Complex World, Canberra, Australia: Australian Strategic Policy Institute, 2005; Evelyn Goh, "The US-China Relationship and Asia-Pacific Security: Negotiating Change," Asian Security, Vol. 1, No. 3, 2005, pp. 216-44; Amitav Acharya, "A Concept of Asia?" Survival, Vol. 41, No. 3, 1999, pp. 84-101; Richard K. Betts, "Wealth, Power and Instability: East Asia and the United States after the Cold War," International Security, Vol. 28, No. 3, 1993-94, pp. 34-77; Douglas T. Stewart, "Towards Concert in Asia," Asian Survey, Vol. 37, No. 3, 1997, pp. 229-244.

35. Christopher Layne, "America's Middle East Grand Strategy after Iraq: The Moment for Offshore Balancing Has Arrived," Review of International Studies, Vol. 35, 2009, pp. 5-25; Christopher Layne, "Offshore Balancing Revisited," The Washington Quarterly, Vol. 25, No. 2, 2002, pp. 233-248; Christopher Layne, The Peace of Illusions: American Grand Strategy from 1940 to the Present, Ithaca, NY: Cornell University Press, 2006; Christopher Layne, "From Preponderance to Offshore Balancing: America's Future Grand Strategy," International Security, Vol. 22, No. 1, 1997, pp. 86-124; Barry Posen, "The Case for Restraint," American Interest, Vol. 3, No. 2, 2007, pp. 7-17; Brian Schmidt, "Offshore Balancing Yesterday and Today," Unpublished paper presented at the Interna- 
tional Studies Association, March 2011; Christopher A. Preble, The Power Problem: How American Military Dominance Makes Us Less Safe, Less Prosperous and Less Free, Ithaca, NY: Cornell University Press, 2009; Stephen M. Walt, Taming American Power: The Global Response to U.S. Primacy, New York: W. W. Norton, 2005, pp. 240-243; Doug Bandow, "First Among Equals," The National Interest, 2009, available from nationalinterest.org/article/first-amongequals-2968.

36. Layne, "From Preponderance to Offshore Balancing," p. 112.

37. Lind, “A Concert-Balance Strategy,” p. 59.

38. Ken Booth and Nicholas J. Wheeler, The Security Dilemma: Fear, Cooperation and Trust in World Politics, New York: Palgrave, 2008, pp. 10-11.

39. Robert Art, "Strategy of Selective Engagement," Kenneth Waltz and Robert J. Art, eds., The Use of Force: Military Power and International Politics, 6th Ed., Lanham, MD: Rowman \& Littlefield, 2003, p. 317.

40. From European history, Josef Joffe identifies British and Bismarckian German precedents for "balancing" and "bonding," presenting these as templates for 21st-century strategy, while cautioning that America must also be a "builder," because war has become too costly to be risked through overly hard balancing. Joseph Joffe, Überpower: The Imperial Temptation of America, New York: W. W. Norton, 2006, pp. 127-157.

41. Paul Kennedy, The Rise and Fall of the Great Powers, New York: Vintage Books, 1989, pp. 357-360.

42. On this case, see Christopher Layne, "The End of Pax Americana: How Western Decline Became Inevitable," The Atlantic, April 2012, available from www.theatlantic.com/international/archive/2012/04/the-end-of-pax-americana-how-western-decline-becameinevitable/256388/; Aaron Friedberg, The Weary Titan: Britain and the Experience of Relative Decline 1895-1905, Princeton, NJ: Princeton University Press, 1989. 
43. Samuel Huntington, "Coping with the Lippmann Gap," Foreign Affairs, Vol. 66, 1987-88, pp. 453-77, especially p. 457.

44. See Robert Jervis, "Security Regimes," International Organisation, Vol. 36, No. 2, 1982, pp. 357-378; "From Balance to Concert: A Study of International Security Cooperation," World Politics, Vol. 38, No. 1, 1985, pp. 58-79; P. W. Schroeder, "Did the Vienna Settlement Rest on a Balance of Power?" The American Historical Review, Vol. 97, No. 3, 1992, pp. 683-706; R. Elrod, "The Concert of Europe," in R. Matthews, ed., International Conflict and Conflict Management, Saddle River, NJ: Prentice-Hall, 1984, pp. 411-20; M. Rendall, "Defensive Realism and the Concert of Europe," Review of International Studies, Vol. 32, No. 3, 2006, pp. 523-541; W. H. Daugherty, "System Management and the Endurance of the Concert of Europe," in J. Snyder and R. Jervis, eds., Coping with Complexity in the International System, Boulder, CO: Westview Press, 1993, pp. 71-107.

45. See Dan Nexon, "A Quarter Baked Idea: The Post-Cold War Concert System," February 11, 2012, available from duckofminerva.blogspot.co.uk/2012/02/quarter-baked-idea-post-cold-war.html.

46. Robert Pape and James Feldman, Cutting the Fuse: The Explosion of Global Suicide Terrorism and How to Stop It, Chicago, IL: University of Chicago Press, 2010.

47. John Mearsheimer, "Imperial by Design," National Interest, Vol. 111, 2011, pp. 16-34; "Pull those Boots off the Ground: The Best Strategy for a Critical Region Is to Withdraw the Troops and Return to Balance-of-Power Politics," Newsweek, December 30, 2008.

48. See Peter Beinart, “Obama's Foreign Policy Doctrine Finally Emerges with 'Offshore Balancing'," The Daily Beast, November 28, 2011 available from www.thedailybeast.com/articles/2011/11/28/ obama-s-foreign-policy-doctrine-finally-emerges-with-off-shorebalancing.html.

49. Sustaining U.S. Global Leadership: Priorities for 21st Century Defense, Washington, DC: Department of Defense, January 2012. 
50. Glenn Kessler, "Clinton Declares 'New Moment' in U.S. Foreign Policy Speech," The Washington Post, September 9, 2010.

51. Hillary Clinton, "Remarks at the U.S. Institute of Peace China Conference," Washington, DC: United States Institute of Peace, March 7, 2012.

52. The White House, Office of the Press Secretary, "Remarks by President Obama to the Australian Parliament," November 17, 2011, available from www.whitehouse.gov/the-pressoffice/2011/11/17/remarks-president-obama-australian-parliament.

53. This has taken the form of agreements on defense relations, space technology, civilian nuclear cooperation, and the establishment of a strategic dialogue between the Secretary of State and the External Affairs Minister. See Mayang A. Rahawestri, "Obama's Foreign Policy in Asia: More Continuity than Change," Security Challenges, Vol. 6, No. 1, 2010, pp. 109-120, especially p. 115.

54. Andrew J. Nathan and Andrew Scobell, "How China Sees America: The Sum of Beijing's Fears," Foreign Affairs, Vol. 91, No. 5, 2012, pp. 32-47, especially pp. 44-45.

55. For criticisms of Concert-Balance strategies and retrenchment more broadly, see Aaron Friedberg, A Contest for Supremacy: China, America and the Struggle for Mastery in Asia, New York: W. W. Norton, 2011, pp. 255-263; James R. Holmes and Toshi Yoshihara, "An Ocean Too Far: Offshore Balancing in the Indian Ocean," Asian Security, Vol. 8, No. 1, 2012, pp. 1-26; Michèle Flournoy and Janine Davidson, "Obama's New Global Posture: The Logic of US Foreign Deployments," Foreign Affairs, Vol. 91, No. 4, 2012, pp. 54-63; Toshi Yoshihara, "Resident Power: The Case for An Enhanced US Military Presence in Australia," July 2011, Sidney, Australlia: MacArthur Foundation/Lowry Institute, Snapshot 9, available from www.lowyinstitute.org/files/pubfiles/Yoshihara,_Resident_power_SS9_web.pdf; Robert G. Kaufman, In Defense of the Bush Doctrine, Lexington, KY: University Press of Kentucky, 2008, pp. 47-48; Sandy Gordon, "The Quest for a Concert of Powers in Asia," Security Challenges, Vol. 8, No. 4, 2012, pp. 35-55. The major theoretical alternative and basis for U.S. primacy in the international relations marketplace is "Hegemonic Stabil- 
ity Theory." See S. G. Brooks and W. C. Wohlforth: World Out of Balance, Princeton, NJ: Princeton University Press, 2008; William C. Wohlforth, "The Stability of a Unipolar World," International Security, Vol. 24, No. 1, 1999, pp. 5-41, especially pp. 23-24.

56. Friedberg, A Contest for Supremacy, p. 254.

57. Flournoy and Davidson, “Obama's New Global Posture," p. 56.

58. International Institute of Strategic Studies, The Military Balance 2012, London, UK: Routledge, 2012, pp. 205-302.

59. Paul Bracken, Fire in the East, New York: Harper, 1999, p. 48.

60. In his words, "Like the recently ended Cold War, these future cold wars would be a blend of arms races, embargoes, and indirect proxy wars of the kind that were fought in Korea, Vietnam, and Soviet-era Afghanistan." Lind, "A Concert/Balance Strategy," p. 56.

61. Andrew F. Krepinevich, 7 Deadly Scenarios: A Military Futurist Explores War in The 21st Century, New York: Bantam, 2009, p. 192.

62. Stephen M. Walt, The Origins of Alliances, Ithaca, NY: Cornell University Press, 1987, pp. 147-181.

63. This argument is drawn from an ealier article by Patrick Porter, "Hooked on Security: Keep NATO, but Curb Its Appetite," The World Today, Vol. 66, No. 10, 2010, pp. 12-14, especially p. 14.

64. One point of debate is the cultural dimension - to what extent was the concert underpinned by an evolving sense of the "common good" that rested not only on common material threats but on a sense of collective identity? Adam Watson, The Evolution of International Society, London, UK: Routledge, 1992, pp. 238ff; K. J. Holsti, "Governance without Government: Polyarchy in Nineteenth Century European International Politics," in James N. Rosenau and Ernst-Otto Czempiel, Governance Without 
Government, New York: Cambridge University Press, 1992, pp. 30-57.

65. For more discussion of these problems, see Jervis, "Security Regimes."

66. Problems identified by Gordon, "The Quest for a Concert of Powers in Asia," p. 36.

67. As argued by Carsten Holbraad in The Concert of Europe: A Study in German and British Institutional Theory 1815-1914, London, UK: Longmans, 1970.

68. Hugh White, for one, has attracted this charge. See Michael Danby, Carl Ungerer, and Peter Khalil, "No Winners by Appeasing China," The Australian, September 16, 2010.

69. See David B. MacDonald, Thinking History, Fighting Evil: Neoconservatives and the Perils of Analogy in American Politics, Lexington, VA: Lexington Books, 2009; Jeffrey Record, "Retiring Hitler and 'Appeasement' from the National Security Debate," $\mathrm{Pa}$ rameters, Vol. 38, 2008, pp. 91-101; Yuen Foong Khong, Analogies at War: Korea, Munich, Dien Bien Phu, and the Vietnam Decisions of 1965, Princeton, NJ: Princeton University Press, 1992; Christopher Layne, "Security Studies and the Use of History: Neville Chamberlain's Grand Strategy Revisited," Security Studies, Vol. 17, 2008, pp. 397-437.

70. Stephen Walt, “The 'Goldilocks Problem' in East Asia," September 3, 2012, available from walt.foreignpolicy.com/ posts/2012/09/03/the_goldilocks_problem_in_east_asia.

71. David Brewster, "The Australia-India Security Declaration: The Quadrilateral Redux?" Security Challengers, Vol. 6, No. 1, 2010, pp. 1-9.

72. Such as G. John Ikenberry, "The Rise of China: Power, Institutions, and the Western Order," in Robert S. Ross and Zhu Feng, eds., China's Ascent: Power, Security and the Future of International Politics, Ithaca, NY: Cornell University Press, 2008, pp. 89114, especially pp. 111-113. 
73. See James Rickards, "Currency Wars: The Making of the Next Global Crisis," New York: Penguin, 2011, pp. 41-42.

74. Gordon, p. 53.

75. For the literature on offence-defense balance and conflict, see Tang Shiping, "Offence-Defence Theory: Towards a Definitive Understanding," Chinese Journal of International Politics, Vol. 3, No. 2, 2010, pp. 213-260; Stephen Van Evera, "Offense, Defence, and the Causes of War," International Security, Vol. 22, No. 4, 1998, pp. 5-43; Robert Jervis, "Cooperation under the Security Dilemma," World Politics, Vol. 30, No. 2, 1978, pp. 167-214.

76. See Steven Van Evera, "A Farewell to Geopolitics," in Leffler and Legro, eds., To Lead the World, pp. 11-36, especially pp. 12-14; Andrew Krepinevich, Barry Watts, and Robert Work, Meeting the Anti-Access and Area-Denial Challenge, Washington DC: Center for Strategic and Budgetary Assessments, 2003, pp. ii, 3. This section is drawn partly from Porter, "A Matter of Choice: Strategy and Discretion in the Shadow of World War Two," Journal of Strategic Studies, Vol. 35, No. 3, 2012, pp. 317-343, especially p. 338.

77. Posen and Ross, “Competing Visions," p. 20.

78. Robert Kagan, "Neocon Nation: Neoconservatism c.1776," World Affairs Journal, 2008, pp. 13-36; see also Justin Logan, "Beltway brigadier Robert Kagan is all wrong," The American Conservative, February 13, 2011, available from www.theamerican conservative.com/articles/best-defense/.

79. Daniel W. Drezner, "The Realist Tradition in American Public Opinion," Perspectives on Politics, Vol. 6, No. 1, 2008, pp. 5170; Christopher A. Preble, The Power Problem: How American Military Dominance Makes Us Less Safe, Less Prosperous and Less Free, Ithaca, NY: Cornell University Press, 2009, pp. 10-11, 64-65.

80. Cited in Drezner, “The Realist Tradition," p. 58.

81. In national polls summarized in September 2012, those interviewed consistently identified the economy and jobs as the most important issues, with only small percentages identifying the wars in Iraq and Afghanistan as most important. "Prob- 
lems and Priorities," PollingReport.com, available from www. pollingreport.com/prioriti.htm.

82. According to the Chicago Council on Global Affairs survey of July 2006, only 10 percent of respondents wanted the United States to "remain the preeminent world leader . . . in solving international problems," while 75 percent believed the United States "should do its share to solve world problems together with other countries"; 76 percent of Americans agreed that "the U.S. is playing the role of world policeman more than it should be." Discussed further in Preble, The Power Problem, pp. 133-134.

83. Pew Research Center poll conducted for the Council on Foreign Relations: "Views of Middle East Unchanged by Recent Events: Public Remains Wary of Global Engagement," June 10, 2011, availaable from www.people-press.org/2011/06/10/views-ofmiddle-east-unchanged-by-recent-events/.

84. For how the Korean War highlighted this problem, see Stephen Casey, Selling Korea: Propaganda, Politics and Public Opinion 1950-1953, Oxford, UK: Oxford University Press, 2008, pp. 20533; Campbell Craig and Fredrik Logevall, America's Cold War: The Politics of Insecurity, Cambridge, MA: Harvard University Press, 2009, pp. 124-25; Patrick Porter, "Beyond the American Century: Walter Lippmann and American Grand Strategy, 1943-1950," Diplomacy and Statecraft, Vol. 22, 2011, pp. 557-577, especially pp. $568,572$.

85. Christopher Layne, Peace of Illusions, pp. 186-192; Benjamin Schwarz and Christopher Layne, "A New Grand Strategy," Atlantic Monthly, 2002, pp. 36-42; Eugene Gholz, Daryl G. Press, and Harvey M. Sapolsky, "Come Home America: The Strategy of Restraint in the Face of Temptation," International Security, Vol. 21, No. 4, 1997, pp. 5-48, especially pp. 17-30.

86. Barry Posen, "The Case for Restraint," American Interest, Vol. 3, No. 2, 2007, pp. 7-17, especially p.16.

87. Barry Posen and Andrew L. Ross, "Competing Visions for U.S. Grand Strategy," International Security, Vol. 21, No. 3, 1996/7, p. 16. 
88. Bruce Gilley, "Not so Dire Straits. How the Finlandization of Taiwan Benefits US Security," Foreign Affairs, Vol. 89, No. 1, 2010, pp. 44-60; Charles Glaser, "Will China's Rise Lead to War? Why Realism Does Not Mean Pessimism," Foreign Affairs, Vol. 90, No. 2, 2011, pp. 80-91; Walter A. McDougall, "History and Strategies: Grand, Maritime, and American," The Telegram, Vol. 6, October 2011; Hugh White, The China Choice: Why America should Share Power, Collingwood, Ontario, Canada: Black Ink, 2012.

\section{McDougall.}

90. For this argument in full, see Gilley, "Not so Dire Straits," pp. 58-59.

91. See Daryl G. Press, Calculating Credibility: How Leaders Assess Military Threats, Ithaca, NY: Cornell University Press, 2007.

92. Micah Zenko and Michael A. Cohen, "Clear and Present Safety: The United States is Safer than Washington Thinks," Foreign Affairs, Vol. 91, No. 2, 2012, pp. 79-93, especially p.88.

93. Mark Dodd, "Bring China into war games, says US admiral, as maritime tensions unresolved at ASEAN," The Australian, July 14, 2012.

94. John Kent, "US Warns on China Sub Encounter," BBC News, November 14, 2006, available from news.bbc.co.uk/1/hi/ world/asia-pacific/6146520.stm.

95. On the debate in the United States over the weaponization of space, see James Clay Moltz, The Politics of Space Security: Strategic Restraint and the Pursuit of National Interests, Palo Alto, CA: Stanford University Press, 2008; Asia's Space Race: National Motivations, Regional Rivalries, and International Risks, New York: Columbia University Press, 2011; Michael Krepon, Space Assurance or Space Dominance? The Case Against Weaponizing Space, Washington, DC: The Henry L. Stimson Center, 2003.

96. As The Washington Times reports, "The initiative will seek to outline international norms for non-threatening behavior in space; to increase transparency among nations that use space; and to reduce the hazards of debris, such as the more than 10,000 
pieces of space junk left by China's 2007 anti-satellite missile test that are orbiting Earth"; Bill Gertz, "New Space Arms-Control Initiative draws Concern," The Washington Times, January 16, 2012.

97. Barry R. Posen, "Command of the Commons: The Military Foundations of U.S. Hegemony," International Security, Vol. 28, No. 1, 2003, pp. 5-46, especially p.12 n25, and p. 20.

98. George F. Kennan, "A Fateful Error," The New York Times, February 5, 1997, p. A23.

99. As argued also by Hachigian and Sutphen, The Next American Century, pp. 197ff.

100. See Andrew Erickson and Gabe Collins, "China's Ballistic Missiles: A Force to be Reckoned With," The Wall Street Journal, August 24, 2012; Keith Bradsher, "China is Said to be Bolstering Missile Capabilities," The New York Times August 24, 2012. 


\section{U.S. ARMY WAR COLLEGE}

Major General Anthony A. Cucolo III

Commandant

\section{***** \\ STRATEGIC STUDIES INSTITUTE and \\ U.S. ARMY WAR COLLEGE PRESS}

Director

Professor Douglas C. Lovelace, Jr.

Director of Research

Dr. Steven K. Metz

Author

Dr. Patrick Porter

Editor for Production

Dr. James G. Pierce

Publications Assistant

Ms. Rita A. Rummel

*****

Composition

Mrs. Jennifer E. Nevil 

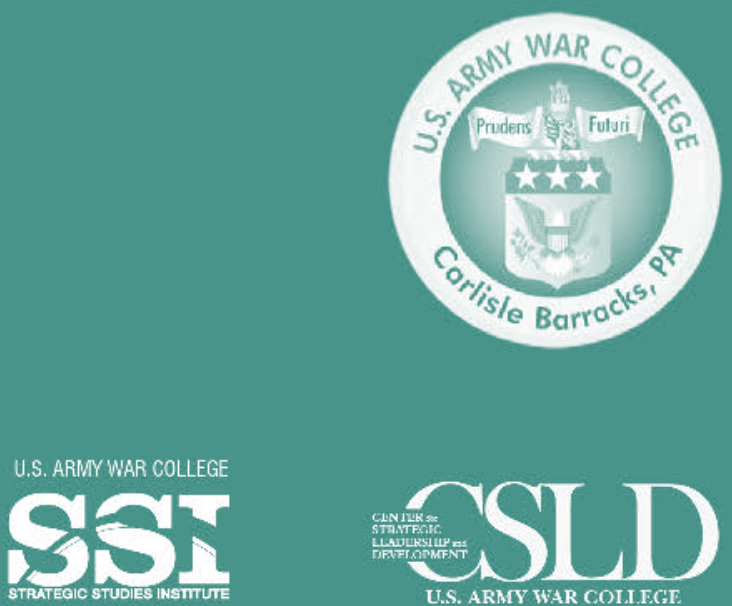
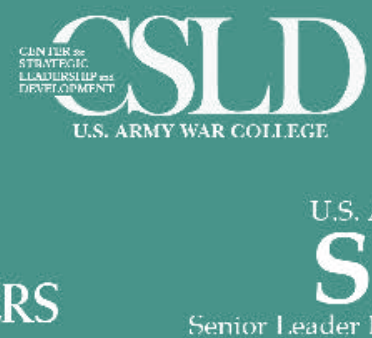

US. ARMY WAR COIIIEGE

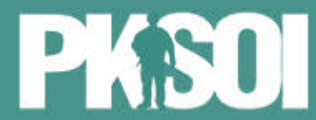

U.S. Army War College

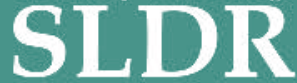

Senior I eader Development and Resiliency
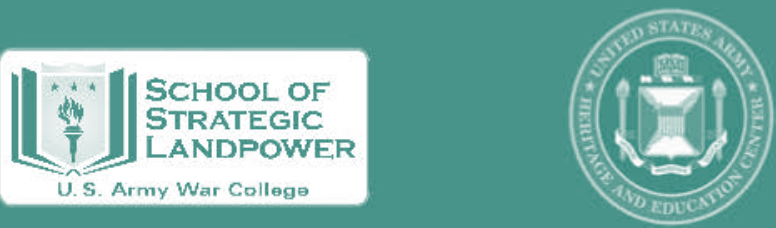

FOR THIS AND OTHER PUBLICATIONS, VISIT US AT http://www.carlisle.army.mil/
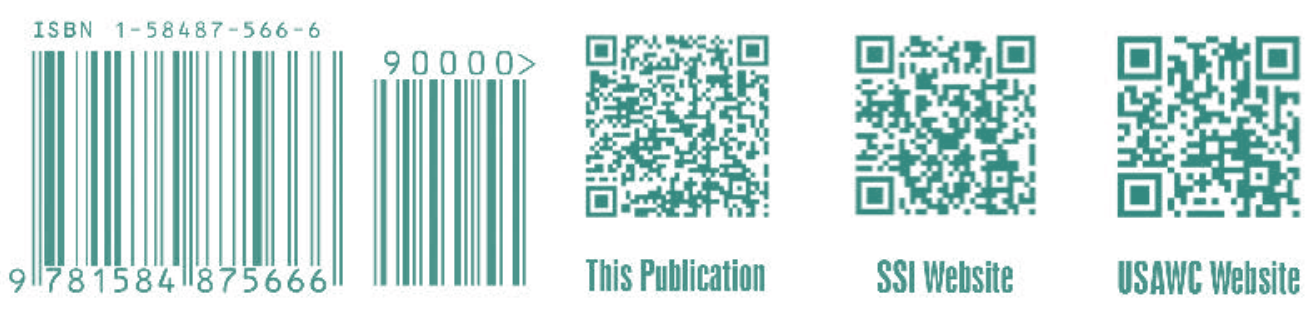

This Publication

SSI Welusite

USAWC Wensite 